\title{
Lower Aeronian triangulate monograptids of the genus Demirastrites Eisel, 1912: biostratigraphy, palaeobiogeography, anagenetic changes and speciation
}

\author{
Petr Štorch \& Michael J. Melchin
}

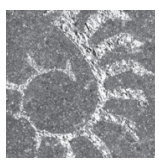

\begin{abstract}
Bed-by-bed sampling of the lower Aeronian black shale succession exposed at the Hlásná Třeban̆ section in the Prague Synform of the Czech Republic has provided a rich and continuous fossil record of biostratigraphically important "triangulate monograptid" graptolites referred to the genus Demirastrites Eisel, whose diagnosis is revised. Eight morphological forms assigned to four species, including the biozonal index taxa Demirastrites triangulatus (Harkness) and D. pectinatus (Richter), as well as D. major (Elles \& Wood) and D. campograptoides sp. nov., are distinguished and described. Also documented are patterns of morphological change within species that we interpret to be anagenetic changes, as well as apparent patterns of morphological divergence that we interpret to represent speciation events. The proposed phylogeny suggests that the $D$. triangulatus lineage underwent significant anagenetic changes throughout its range before it split at the base of the pectinatus Biozone and gave rise to D. pectinatus, which then underwent further anagenetic changes between its early and late forms. At a slightly later stage, in the lower pectinatus Biozone, the $D$. triangulatus stem lineage underwent further significant changes, giving rise to D. major, which then saw further significant anagenetic changes before it became extinct in the middle pectinatus Biozone, well below the highest occurrence of $D$. pectinatus. D. campograptoides is a rare and apparently short-ranging species, thus far recorded only from Bohemia, derived from either early D. triangulatus or its direct ancestor. Reconsideration of the species' records worldwide suggest that none of these lower Aeronian forms was truly cosmopolitan. Key words: graptolite, Silurian, Aeronian, zonal index species, stratigraphy, taxonomy, evolution, intraspecific variability, Prague Synform, Czech Republic.
\end{abstract}

ŠTorch, P. \& Melchin, M.J. 2018. Lower Aeronian triangulate monograptids of the genus Demirastrites Eisel, 1912: biostratigraphy, palaeobiogeography, anagenetic changes and speciation. Bulletin of Geosciences 93(4), 513-537 (12 figures, 1 table). Czech Geological Survey, Prague. ISSN 1214-1119. Manuscript received October 31, 2018; accepted in revised form December 3, 2018; published online December 20, 2018; issued December 20, 2018.

Petr Štorch, Institute of Geology CAS, Rozvojová 269, Praha 6, 16502, Czech Republic; storch@gli.cas.cz • Michael J. Melchin, Department of Earth Sciences, St. Francis Xavier Univeristy, Antigonish, Nova Scotia, B2G 2W5, Canada

Global correlation of Silurian rocks relies, to a large extent, on planktonic graptolites, the most common and diversified macrofossils to be found in anoxic black shales, which are widespread in off-shore depositional settings, particularly in the lower part of the Silurian System. High-resolution correlation, particularly quantitative stratigraphical correlation based upon semi-automated (Shaw's graphic correlation: Shaw 1964, Cooper \& Lindholm 1990, Fan et al. 2013) and automated systems (CONOP: Sadler et al. 2003, 2011; Sadler 2004; Cooper et al. 2014 and Horizon Annealing: Sheets et al. 2012, Melchin et al. 2016a) have demanding requirements for primary data input. Densely sampled sections with abundant and highly diversified graptolite faunas are just one step on the way to maximum resolution in stratigraphy and correlation, which also relies critically on the correct taxonomic assignment of the taxa involved. Modern taxonomic revisions are needed not only for the purpose of high-resolution stratigraphy and correlation, but also correct determination of the taxa is a primary prerequisite for any palaeobiogeographical analysis, particularly when closely similar taxa occur in a similar, but not always the same, stratigraphical interval in different palaeobiogeographical provinces.

The present study focusses on the systematic revision of lower Aeronian monograptids with proximal rastritiform to sub-rastritiform thecae and non-overlapping, subrastritiform to high-triangular distal thecae with hooked apertures that are transversely extended into a pair of lateral apertural processes. These graptolites are of particular importance in lower Aeronian graptolite biostratigraphy 
worldwide. They were often reported by earlier authors as an informal group of "triangulate monograptids" and assigned to the broadly based genus Monograptus (see e.g. Sudbury 1958, Rickards 1970, Hutt 1975, Rickards et al. 1977). New insights into graptolite thecal morphologies and recognition of several similar monograptid genera Campograptus (Obut et al. 1968), Lituigraptus (Ni, 1978) and Torquigraptus (Loydell, 1993) - restricted some of the remaining "triangulate monograptids" to species with rhabdosomal and thecal forms that correspond with those of the genus Demirastrites (Eisel, 1912), as diagnosed by Přibyl \& Münch (1942) and Štorch (2015).

The first appearance datum of Demirastrites triangulatus (Harkness, 1851), the type species of the genus and biozonal index fossil of the lowermost Aeronian graptolite biozone, has been widely used as a marker of the base of the Aeronian Stage (e.g. Štorch 1994, Melchin et al. 2012, Štorch et al. 2018). Although some fragmentary specimens with similar isolated thecae, assigned questionably to Demirastrites brevis (Sudbury, 1958), have been found in strata as low as the topmost Rhuddanian of the Rheidol Gorge section (uppermost Coronograptus cyphus Biozone - Melchin et al. 2018), the first appearance and abrupt proliferation of $D$. triangulatus marks lowermost Aeronian strata and began a rapid Aeronian expansion of monograptids with more-or-less isolated and hooked metathecae (Demirastrites, Campograptus, Rastrites, Lituigraptus, Torquigraptus and some species provisionally retained in "Monograptus"). Although Demirastrites triangulatus and its eponymous biozone have been reported from Siberia (e.g. Obut et al. 1968) and China (Chen \& Lin 1978, Anhui Geological Survey 1982, Li 1995), specimens assigned to $D$. triangulatus in Siberia and China differ from the European form in their lesser dorso-ventral width (DVW), less prominent thecal apertural processes and some other morphological details. Demirastrites pectinatus (Richter, 1853), likely a descendant of $D$. triangulatus, has been employed as an index species of a graptolite biozone overlying the $D$. triangulatus Biozone in peri-Gondwanan Europe (e.g. Bouček 1953, Štorch 1994, Loydell 2012) and as a subzonal index in Arctic Canada (Melchin 1989, Melchin \& Holmden 2006). It is the senior synonym of Monograptus fimbriatus (Nicholson, 1868) (e.g. Bjerreskov 1975), commonly reported from the same stratigraphical interval in Britain, which was assigned to the upper D. triangulatus Biozone by Zalasiewicz et al. (2009).

A continuous, stratigraphically ordered morphological series of "triangulate monograptids" assigned to Monograptus fimbriatus, M. raitzhainensis and M. triangulatus was first recorded and interpreted by Challinor (1945) from Rheidol Gorge, Wales. Based on more detailed systematic study of larger, more densely sampled collections of well-preserved, pyrite-infilled specimens from the Rheidol Gorge section, Sudbury (1958) revised

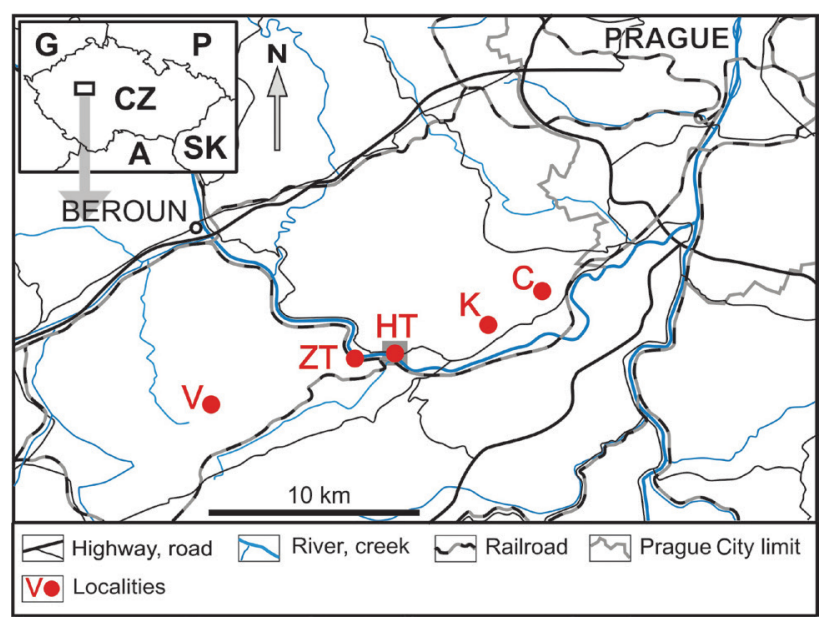

Figure 1. Location map of the Hlásná Třebaň section and other localities within the Prague Synform. Abbreviations: HT - Hlásná Třebaň

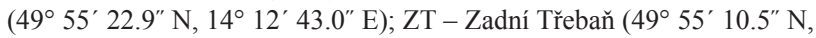
$\left.14^{\circ} 11^{\prime} 5.8^{\prime \prime} \mathrm{E}\right) ; \mathrm{K}-$ Karlík (49 $\left.59^{\circ} 30.0^{\prime \prime} \mathrm{N}, 14^{\circ} 16^{\prime} 8.6^{\prime \prime} \mathrm{E}\right)$; $\mathrm{C}$ - Černošice $\left(49^{\circ} 57^{\prime} 27.1^{\prime \prime} \mathrm{N}, 14^{\circ} 18^{\prime} 23.0^{\prime \prime} \mathrm{E}\right)$; V - Všeradice $\left(49^{\circ} 52^{\prime} 36.3^{\prime \prime} \mathrm{N}, 14^{\circ} 6^{\prime} 12.9^{\prime \prime}\right.$ E). See Štorch (2015) and Štorch et al. (2018) for locality details.

the interpretions of the proposed lineages among the taxa preserved at that section and brought substantial progress in our understanding of the morphological details and the stratigraphical succession of the "triangulate monograptids". In particular, Sudbury (1958, fig. 24) proposed a hypothesis for the evolution of members of the $D$. triangulatus group based on data from the Rheidol Gorge section. It is important to note that Sudbury (1958) had named the various members of the triangulatus group as subspecies of Monograptus separatus, but later corrected this, recognizing that the name Monograptus triangulatus had priority over M. separatus (Sudbury 1959). Her study of the evolutionary relationships among the members of the Monograptus triangulatus group spanned the lower part of the gregarius Biozone, an interval that is now recognized as the lower to upper part of the M. triangulatus Biozone of Zalasiewicz et al. (2009), which correlates with the D. triangulatus Biozone and lower part of Demirastrites pectinatus Biozone of continental Europe (see Melchin et al. 2018). Lower Aeronian graptolites of the Rheidol Gorge section, a locality proposed as one of the candidate sections for the new base Aeronian GSSP (Melchin et al. 2016b, 2018), are confined to a number of black-shale bands interbedded with graptolite-barren mudstones (Jones 1909, Sudbury 1958, Cullum \& Loydell 2011, Melchin et al. 2018). As a result of the unfossiliferous intervals, the record of graptolite evolution is not complete in that section. Rhabdosomes collected from some fossiliferous bands are preserved in full relief but affected by varying degrees of brittle cleavage deformation. Also, some apertural details are not completely preserved in the pyrite internal moulds. No chemically etched specimens of undoubted members 
Petr Štorch \& Michael J. Melchin • Lower Aeronian triangulate monograptids

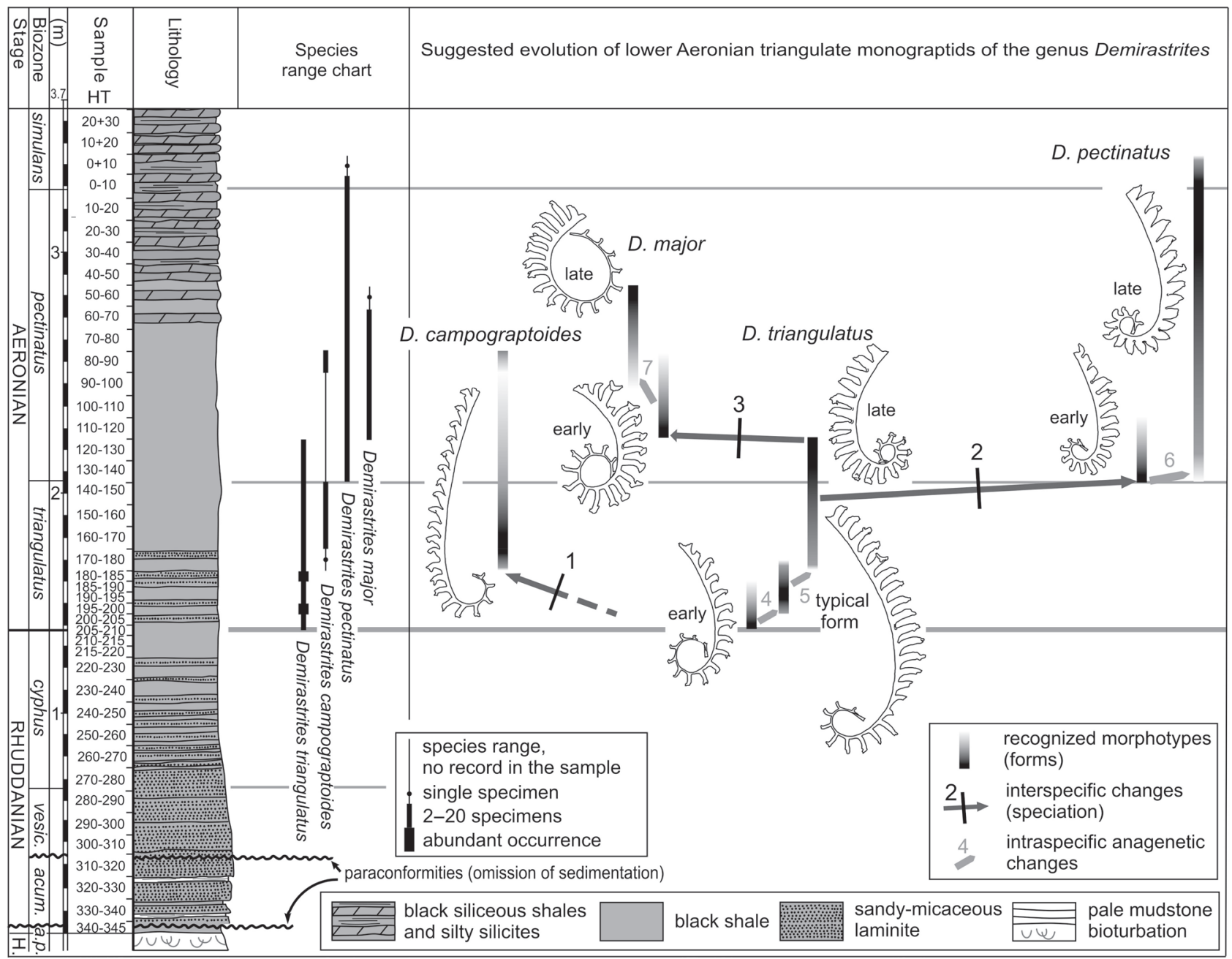

Figure 2. Stratigraphical ranges and proposed evolution of lower Aeronian demirastritids based on the fossil record from the Hlásná Třebaň section. Morphological modifications attributed to speciation: 1 - early derivation of $D$. campograptoides from demirastritid stem-line through rapid transition from a few rastritid proximal thecae to robust, slightly hooked distal thecae is tentatively suggested; 2 - origin of $D$. pectinatus from late form of $D$. triangulatus marked by prothecal shortening and rapid decrease of thecal isolation, increasing thecal width (robustness), significant shortening of lateral apertural processes and lessening of the DVW and of proximal dorsal curvature of the rhabdosome; 3 - origin of D. major resulted in more densely spaced, ventrally curved sub-rastritiform metathecae, which became significantly longer at the expense of the prothecal part (greater DVW and lesser 2TRD in mesial and distal part of the rhabdosome), and maximum extension of lateral apertural processes. Gradual shift in some of the morphological characters has been ascribed to anagenetic changes; 4 - typical form of $D$. triangulatus developed from the early morphotype by developing several fully rastritiform thecae near the proximal end, and more densely spaced thecae in the distal part of the rhabdosome. Theca 1 and th2 became higher, the rhabdosome width increased more rapidly; 5 - relatively short ranging typical form was soon replaced by specimens of the late form with tightly coiled proximal part and more densely spaced and less inclined thecae furnished with more strongly developed apertural processes; $6-D$. pectinatus recorded progressive lessening of mesial and distal DVW in stratigraphically higher specimens, in part due to lower thecal inclination, and further lessening of thecal isolation; $7-D$. major went through progressive straightening and remarkable protraction of the proximal part having proximal prothecae substantially elongated at the expense of metathecae. Abbreviations: $p$. - persculptus Biozone; a. - ascensus Biozone; acum. - acuminatus Biozone; vesic. - vesiculosus Biozone; H - Hirnantian. Section log and sampling after Štorch et al. (2018). Simplified drawings of recognized morphotypes $(\times 2)$ are based upon real specimens.

of the $D$. triangulatus group have been previously reported either from Wales or elsewhere.

Detailed examination of the present material from the Hlásná Třebaň section, supplemented with further collections from Všeradice, Černošice and Karlík (Fig. 1), as well as some specimens from Spanish and Austrian localities, has shed more light on high-resolution biostratigraphy, correlation, palaeobiogeography, as well as proposed anagenetic changes and speciation events in the lower Aeronian monograptids assigned to the genus Demirastrites Eisel, 1912. Demirastrites extremus and D. predecipiens, both described by Sudbury (1958, as subspecies of Monograptus separatus), and ?Demirastrites similis (Elles \& Wood, 1913) have not been recognized 
in our collections, nor have they been recorded with certainty elsewhere in continental Europe. Demirastrites triangulatus separatus (Sudbury, 1958) is not regarded here as a distinct subspecies of $D$. triangulatus (see discussion of this species below).

The present study, based on bed-by-bed sampling of the continuously fossiliferous Hlásná Třebaň section, with abundant, albeit flattened specimens of Demirastrites, has enabled detailed insights into the morphological changes through the stratigraphical ranges of the species present: D. triangulatus (Harkness), D. major (Elles \& Wood), D. pectinatus (Richter) and D. campograptoides sp. nov. (Fig. 2). Specimens assigned to "Demirastrites" brevis (Sudbury 1958) (originally named Monograptus toernquisti brevis) also occur in the $D$. triangulatus Biozone at Hlásná Třebaň (Štorch et al. 2018). This taxon is not included in this study because our available specimens are too sparse and incomplete, consisting only of near-proximal to mesial fragments, for complete documentation of its morphology and phylogenetic relationships. In addition, although the distal thecae of this species, as it is known from the type material, are sub-rastritiform, similar to those of early forms of $D$. triangulatus (although shorter), the proximal three to four thecae are highly axially elongate, so there is some question as to whether this species should be assigned to Demirastrites.

\section{Material and methods}

This study is based mainly on 218 specimens of Demirastrites, which were well enough preserved for detailed morphometric analysis, collected from the Demirastrites triangulatus and D. pectinatus biozones, sampled bedby-bed from the base Aeronian GSSP candidate section at Hlásná Třebaň (Štorch et al. 2018). This material has been complemented by other less complete and/or less well-preserved specimens from Hlásná Třebaň, as well as specimens from several other localities within the Prague Synform (Barrandian area of central Bohemia, Czech Republic): Všeradice (Štorch 2015), Zadní Třebaň and Černošice (Štorch 1994). Further specimens employed in this study came from measured lower Aeronian sections in southwestern Spain (El Pintado section, see Loydell et al. 2015) and the Carnic Alps (Oberbuchach Nölblinggraben section, Jaeger \& Schönlaub 1977). The studied specimens are compared with published, well-documented collections from Thuringia (Schauer 1971), Brittany (Piçarra et al. 2009), southwestern Sweden (Törnquist 1899), Bornholm (Bjerreskov 1975, Loydell et al. 2017), Latvia (Loydell et al. 2003), Lithuania (Paškevičius 1979) and the UK (Elles \& Wood 1913, Sudbury 1958, Rickards 1970, Hutt 1975 and MJM personal observation).

In order to complete the systematic revision, vital for correlation and subsequent palaeobiogeographical studies, we also examined specimens from Morocco (PS personal observation, see also Willefert 1963), sections in South China, including material deposited in Nanjing Institute of Geology and Palaeontology, collections from northwestern and Arctic Canada (see also Lenz 1982, Melchin 1989), and published data from Siberia (Obut et al. 1965, 1967, 1968).

Graptolites from Hlásná Třebaň and other Czech sections are preserved as flattened impressions, either carbonized or partly pyritized. Spanish specimens are also flattened but the rhabdosomal material is overgrown by a pale ?chloritic mineral.

For a better understanding of the thecal morphology, study of the flattened material has been supplemented by observations on fragments of Demirastrites ex gr. triangulatus chemically isolated from limestone nodules, studied by scanning electron microscopy, from the pectinatus-triangulatus Subzone of the Cape Manning section, Cornwallis Island, Arctic Canada (see Melchin et al. 2017, for locality details).

The detailed morphological and morphometric analysis, based upon 43 characters, was performed using the 218 most complete and/or best preserved rhabdosomes from Hlásná Třebaň. Additionally, 38 specimens from Všeradice, Zadní Třebaň and Černošice sections and 10 specimens from the Spanish El Pintado Section, were used in determining the ranges of variation in thecal form and dimensions for the species descriptions. In the species decriptions (M) indicates mean value and (n) indicates number of specimens used for calculation of mean values of the respective characters. Mean values were calculated only in those cases where ten or more measurements were available for a particular character. Specimens were photographed with an Olympus BX16 microscope fitted with a Canon EOS 1200D camera, line drawings were made using a camera lucida and traced using Adobe Photoshop software.

The following characters have been measured and/or described (see Fig. 3 for graphic explanation): width of the sicular aperture; sicula length; distance between the sicular aperture and point of origin of th 1 ; location of the sicular apex relative to the base of the dorsal wall of the first metatheca; dorso-ventral width of the rhabdosome (DVW) at th1, 2, 3, 4, 5, 10, and distally; two thecae repeat distance (2TRD sensu Howe 1983) at th2, 3, 5, 10, and distally; total axial length of th1; prothecal tube length of th1, 3, 5 and 10; prothecal width at base of th2, 5, 10 and in distal thecae; metathecal width at the midpoint of the metathecal height at th2, 5, 10 and in distal theca; curvature of the ventral prothecal wall at th 2,5 and 10 ; tapering of the metathecal tube at th2, 5, 10 and in distal thecae; ventral curvature of metathecae; maximum length of the lateral apertural processes in the proximal thecae (th1-5) and distal thecae; angle of metathecal inclination at th2, 5,10 and in distal thecae; angle of rhabdosome curvature 


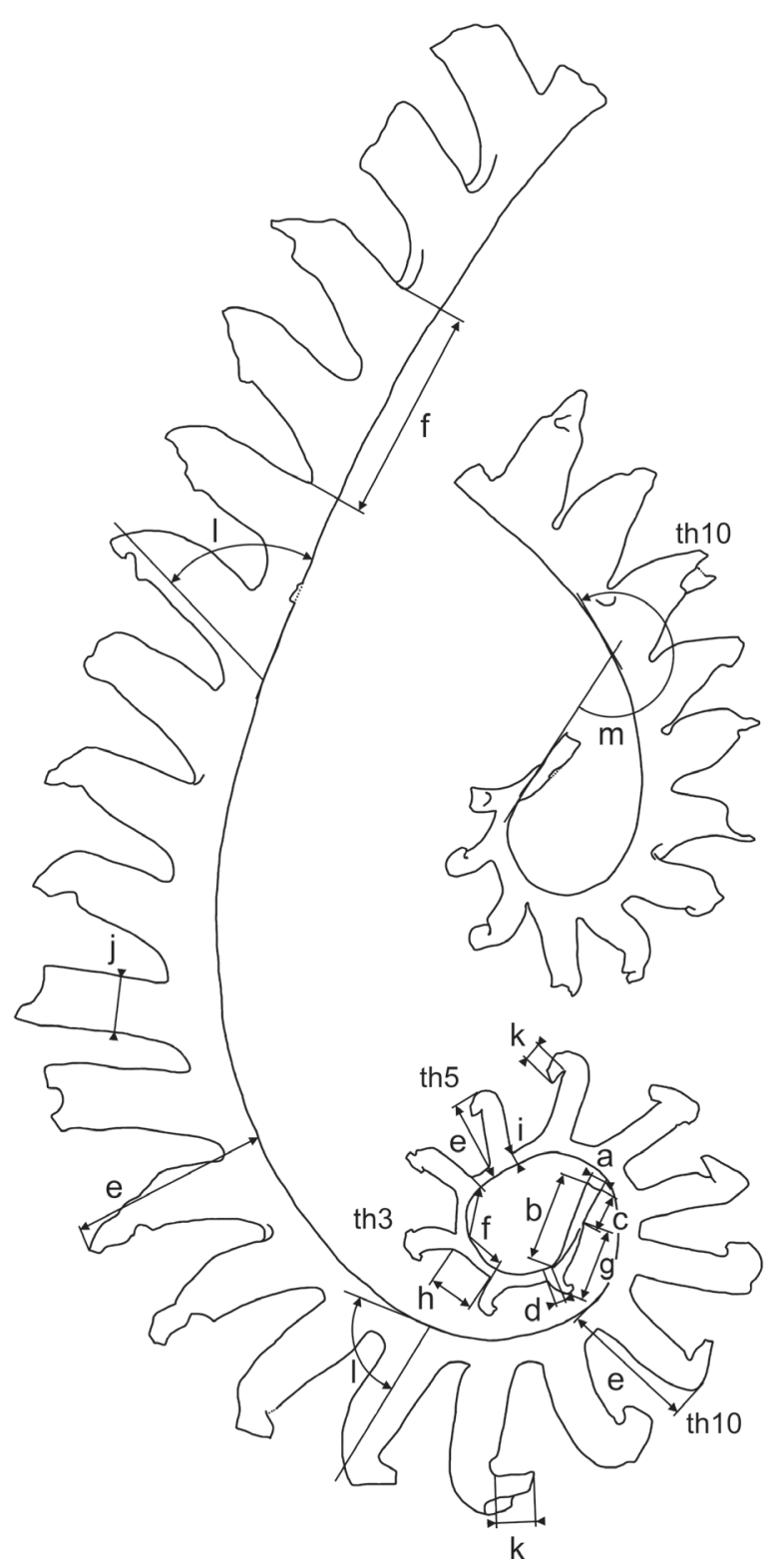

Figure 3. Some of the characters measured on rhabdosomes in this study: $\mathrm{a}$ - width of the sicular aperture; $\mathrm{b}$ - sicula length; $\mathrm{c}$ - distance between the sicular aperture and point of origin of th $1 ; \mathrm{d}$ - location of the sicular apex related to dorsal wall of the first metatheca; $\mathrm{e}$ - dorso-ventral width of the rhabdosome (DVW) at th1, 2, 3, 4, 5, 10, and distally; $\mathrm{f}$ - two thecae repeat distance (2TRD) at th $2,3,5,10$, and distally; $g$ - total axial length of th $1 ; \mathrm{h}$ - length of ventral prothecal wall at th1, 3,5 and $10 ; \mathrm{i}-$ prothecal width at base of th2, 5, 10 and in distal thecae; $\mathrm{j}$ - metathecal width at midpoint of the metathecal height at th2, 5, 10 and at distal theca; $\mathrm{k}-$ length of lateral apertural processes in proximal thecae (th1-5) and distal thecae; 1 - angle of metathecal inclination at th2, 5, 10 and at distal thecae; $\mathrm{m}$ - angle of rhabdosome curvature between th 1 and th 10 .

between the sicula and th10; and, ordinal number of the most distal rastritiform or sub-rastritiform theca.

The graptolite material for this study from the Prague Synform is housed in the Czech Geological Survey,
Prague in a collection prefixed PŠ, and Spanish specimens prefixed MGM are housed in Museo Geominero, Instituto Geológico y Minero de España, Madrid. Type specimens prefixed GSM are housed in British Geological Survey, Keyworth; specimen prefixed SM is housed in Sedgwick Museum, Cambridge; a type specimen prefixed BGR X is housed in the Bundesanstalt für Geowisseschaften und Rohstoffe, Berlin. Specimens from Arctic Canada prefixed ROM are housed in the Royal Ontario Museum, Toronto, and those prefixed GSA are in the type collections of the Geological Survey of Canada in Ottawa.

\section{Comments on overall morphology and taphonomy}

All species of Demirastrites show at least some gradient in their thecal form from the proximal to distal end. The terminology that we employ in this study pertaining to overall thecal form, as well as apertural form, is illustrated in Fig. 4. We restrict the term "rastritiform" thecae to those that possess parallel-sided prothecae and straight, parallel-sided metathecae that emerge at a high angle from the prothecae. If there is a parallel-sided to gradually widening protheca whose ventral wall is clearly distinct (marked by a point of inflection - we refer to this portion of the prothecae as "prothecal tubes") from that of the more erect metatheca but the metathecae are tapering and/or curved, then these are referred to as "sub-rastritiform" thecae. If the ventral wall of the protheca is highly inclined and/or strongly concave and merges smoothly into that of the metatheca with no distinct prothecal tube, and the thecae are high (significantly higher than wide) and triangular in overall form, then the thecae are referred to as "high-triangulate".

The thecal morphology most commonly associated with the genus Demirastrites is fully rastritiform thecae proximally, gradually changing to high-triangulate distally. Many specimens of $D$. triangulatus and $D$. major display this typical morphology. However, some specimens that we have assigned to $D$. triangulatus show slightly tapering and/or slightly curved (sub-rastritiform) (Fig. 4A) proximal metathecae. Many specimens of D. major also show slightly curved proximal metathecae. Demirastrites pectinatus and D. campograptoides are both characterized by possessing sub-rastritiform thecae proximally. In the case of the former species, there are only a few subrastritiform thecae before they change to a high-triangulate form (Fig. 4A). There are also specimens of D. triangulatus and $D$. major that appear to retain the sub-rastritiform thecae, with distinct prothecal tubes, into the distal part of the rhabdosome. It is difficult to know how much of this apparent variation in form of the prothecae is the result of slight differences in the mode of flattening compression, but similar intraspecific variations in prothecal form can 

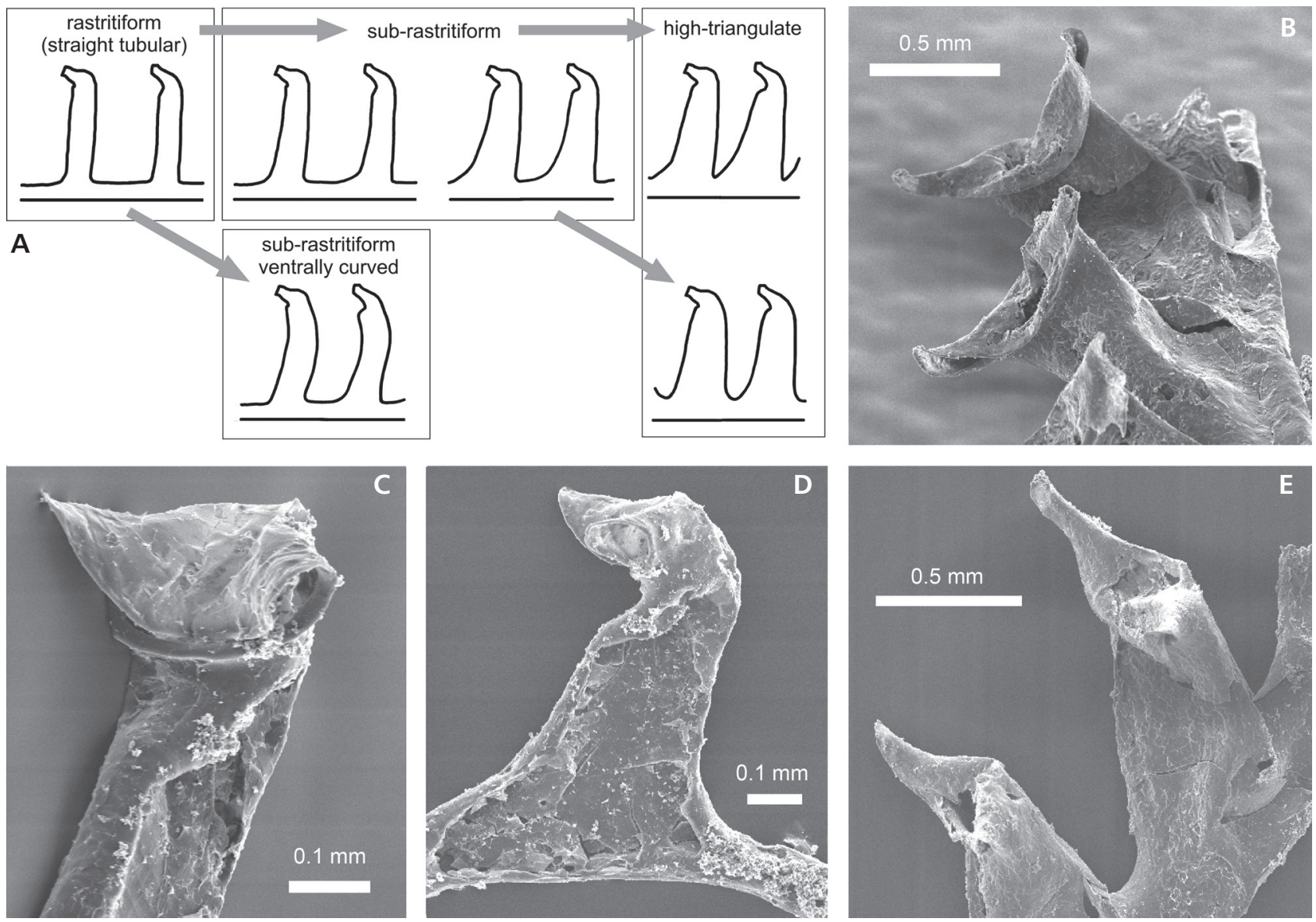

Figure 4. Thecal morphology of the lower Aeronian demirastritids. $\bullet$ A - terminology of thecal profile applied in this study. $\bullet$ B-E - thecal form and apertural details preserved in fragmentary Demirastrites ex gr. triangulatus chemically etched by Dawson (2007) from limestone nodule of the Cape Manning section, Cornwallis Island (sample MCM2 - 98, 47.9-48.0 m; see Melchin et al. 2017, fig. 3). Note narrow, symmetrical, transversely extended thecal apertures projected on both sides into ear-like lateral processes ("horns" of earlier authors); B, E - distal thecae; C, D - proximal thecae.

also be seen in the uncompressed pyrite mould specimens of some of these taxa illustrated by Sudbury (1958; "M. separatus separatus" and "M. separatus fimbriatus" on pl. 19, "M. separatus triangulatus" on pl. 20).

The thecae terminate in relatively narrow, proximally facing apertures, transversely extended into a pair of slightly enrolled lateral processes the concave surfaces of which face proximally to dorso-proximally. This is well illustrated by rare chemically isolated fragments of D. ex gr. triangulatus from Arctic Canada (Fig. 4B-E). The considerable morphological variability observed in the thecal apertures of flattened specimens is most likely a combination of both primary biological variability and secondary taphonomical variation. In particular, the apertural parts of the thecae are variously deformed by differing degrees and angles of flattening. We presume that in the case of burial in relatively soft sediment, the thecae are likely to have been flattened in profile with lateral processes oriented perpendicular to the rhabdosome plane, buried within the under- and overlying soft sediment. In case of "cling-film preservation", in which the sediment surfaces are believed to have been firm due to bacterial mats (Jones et al. 2002), which appears to have been particularly common in Silurian graptolite black shales, the lateral apertural processes are commonly flattened and folded, either one up and one down over the aperture (Figs 7A, C, E; 8R; 9G, K), both folded up (Figs 6D, E; 7C; $8 \mathrm{O}$ ), or both folded down (Figs $5 \mathrm{G}, 8 \mathrm{~L}, 9 \mathrm{~K}$ ), or, in some cases the whole aperture was laterally twisted showing both processes extended in their original horizontal position (Figs 6C; 7E, J; 9B, D, E, P). The lateral apertural processes are usually small in the most proximal thecae and became more prominent in mesial and distal thecae as shown on Fig. 4B-E, for example.

The tightly curved proximal parts of D. major, D. pectinatus and stratigraphically high specimens of $D$. triangulatus, with the sicula and th1 crossing the stipe at the level of about th7, suggest that the rhabdosome had a low helical spiral shape that has been flattened onto a single plane by clingfilm preservation. 


\section{Systematic Palaeontology}

The measurements of dorso-ventral width (DVW) and twothecae repeat distance (2TRD) at several points along the rhabdosome for all described species are presented in Tab. 1.

Family Monograptidae Lapworth, 1873

\section{Genus Demirastrites Eisel, 1912}

Type species. - Demirastrites triangulatus Harkness, 1851, from Frenchland Burn near Moffat, Scotland. Subsequently designated by Přibyl \& Münch (1942, p. 3).

Diagnosis. - (emended from Štorch 2015). Rhabdosome with proximally accentuated dorsal curvature. Sicula small. Thecae isolated, ventral prothecal wall free, parallel to rhabdosome axis, concave or slightly inclined. At least three or four proximal thecae rastritiform to subrastritiform, although th 1 is commonly elongate. Distal thecae either sub-rastritiform or high-triangular. Thecal apertures proximally facing, slightly hooked, narrow, symmetrical, transversely extended into a pair of ear-like lateral apertural processes.

\section{Demirastrites campograptoides sp. nov.}

Figures 5A-G; 6A, H

2015 Demirastrites sp. - Štorch, pp. 885, 886, figs 16c, 17e.

2018 Demirastrites? raitzhainensis (Eisel). - Štorch et al., p. 369 , fig. $7 \mathrm{j}$.

Holotype. - Specimen no. PŠ 3988a from the lower Aeronian middle triangulatus Biozone (sample HT160-170) of the Hlásná Třebaň section, Bohemia; figured by Štorch et al. (2018, p. 369, fig. 7j) and refigured herein in Fig. 5F.

Type horizon and locality. - Lower Aeronian middle triangulatus Biozone, sample HT160-170, Hlásná Třebaň section, Bohemia.

Material. - Ten flattened, more-or-less complete rhabdosomes from the middle-upper triangulatus and lowermost pectinatus biozones of Hlásná Třebaň section, and two incomplete specimens from Všeradice.

Etymology. - Campograptoides, after the distal thecae, which superficially resemble those of coeval species of the genus Campograptus.

Diagnosis. - Rhabdosome dorsally curved, hook-shaped in proximal part, 1.0-1.4 mm wide distally. Sicula small, apex attaining the level of the dorsal wall of the first metatheca.
Thecae markedly biform. Nine to twelve proximal thecae sub-rastritiform. Distal thecae triangular, strongly inclined, numbering 9-10 in $10 \mathrm{~mm}$, terminated by rounded weak hooks with narrow, proximally facing apertures transversely extended into relatively small lateral processes.

Description. - The rhabdosome is dorsally curved throughout, hook-shaped in the proximal part, which is curved through an angle of $180-270^{\circ}$ within 10 proximal thecae. The sicula is $0.7-0.8 \mathrm{~mm}$ long, straight, and $0.16-$

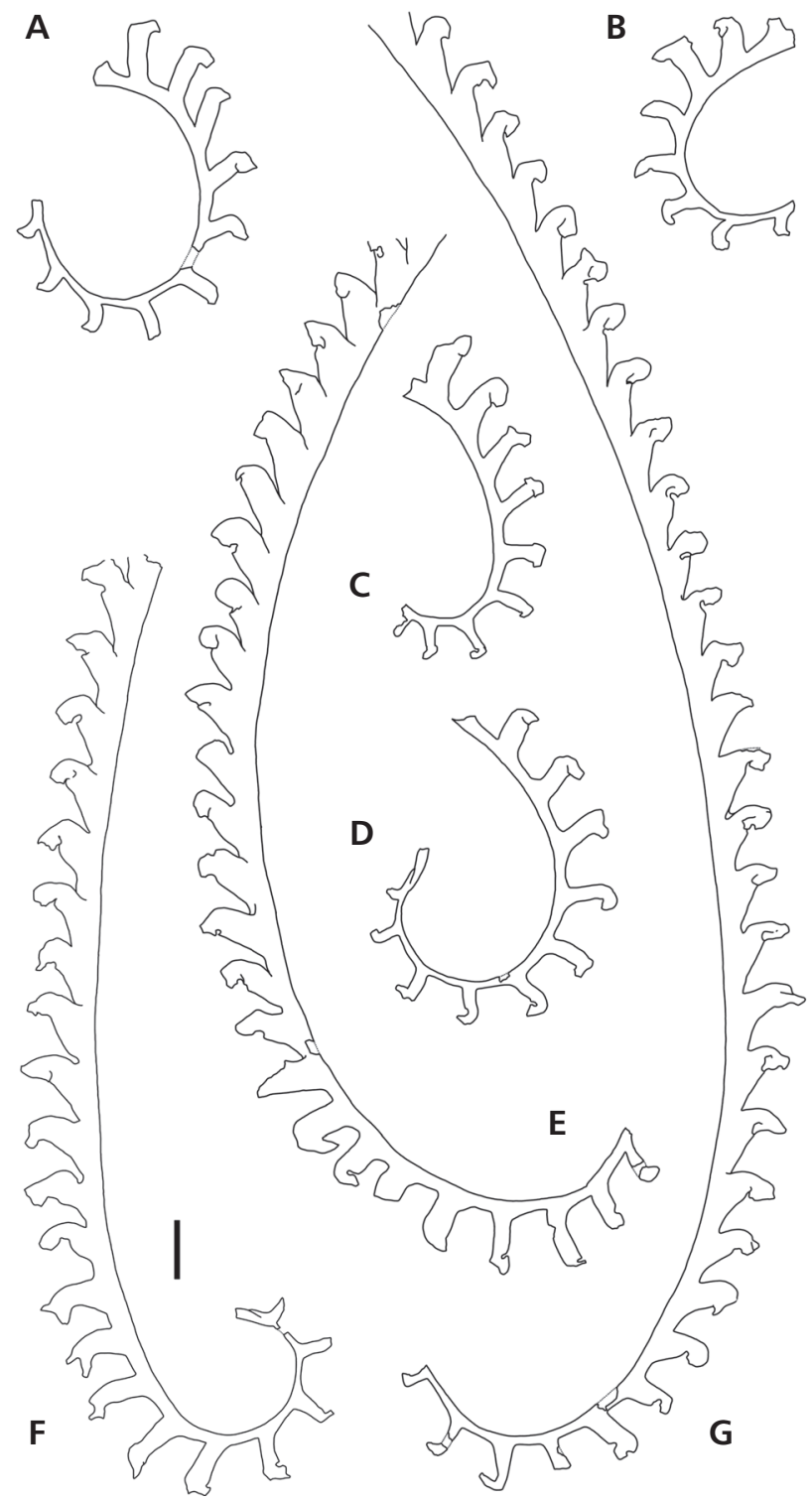

Figure 5. Demirastrites campograptoides sp. nov.; A - PŠ 4235, sample HT150-160; B - PŠ 4308, sample HT150-160; C - PŠ 4302, sample HT160-170; D - PŠ 4033, sample HT160-170; E - PŠ 3991, sample HT150-160; F - PŠ 3988a, holotype, sample HT160-170; G PŠ 4155, sample HT170-180. All specimens from Hlásná Třebaň. All figures $\times 6$, scale bar represents $1 \mathrm{~mm}$. 
Table 1. DVW and 2TRD measurements (in mm). Abbreviations: $M$ - mean value; $n$ - number of specimens; (s) - single specimen measured.

\begin{tabular}{|c|c|c|c|c|c|c|c|c|c|c|c|c|}
\hline \multirow{2}{*}{ Species and form } & \multicolumn{3}{|c|}{ DVW th1 } & \multicolumn{3}{|c|}{ DVW th2 } & \multicolumn{3}{|c|}{ DVW th3 } & \multicolumn{3}{|c|}{ DVW th4 } \\
\hline & range & M & $\mathrm{n}$ & range & M & $\mathrm{n}$ & range & M & $\mathrm{n}$ & range & M & $\mathrm{n}$ \\
\hline D. triangulatus - early & $0.3-0.5$ & 0.38 & 24 & $0.35-0.75$ & 0.55 & 27 & $0.55-0.95$ & 0.72 & 30 & $0.65-1.1$ & 0.81 & 19 \\
\hline D. triangulatus - typical & $0.3-0.5$ & 0.30 & 24 & $0.35-0.13$ & 0.53 & 27 & $0.53-0.95$ & 0.12 & 30 & $0.85-1.15$ & - & - \\
\hline D. triangulatus - late & $0.35-0.55$ & 0.42 & 23 & $0.55-0.75$ & 0.64 & 32 & $0.62-0.98$ & 0.9 & 42 & $0.75-1.15$ & 0.96 & 43 \\
\hline D. major - early & $0.48(\mathrm{~s})$ & - & - & $0.6-0.78$ & - & - & $0.74-0.98$ & - & - & $0.9-1.2$ & - & - \\
\hline D. major - late & - & - & - & $0.4-0.55$ & - & - & $0.63-0.81$ & - & - & $0.63-0.8$ & - & - \\
\hline $\begin{array}{l}\text { D. pectinatus - early } \\
\text { D. pectinatus - late }\end{array}$ & $0.4-0.6$ & 0.5 & 31 & $0.55-0.75$ & 0.65 & 33 & $0.7-0.92$ & 0.81 & 32 & $0.78-1.12$ & 0.89 & 37 \\
\hline D. campograptoides & $0.35-0.55$ & - & - & $0.5-0.65$ & - & - & $0.6-0.85$ & - & - & $0.75-1.0$ & 0.86 & 10 \\
\hline
\end{tabular}

Table 1. continued.

\begin{tabular}{|c|c|c|c|c|c|c|c|c|c|c|c|c|}
\hline \multirow{2}{*}{ Species and form } & \multicolumn{3}{|c|}{ DVW th5 } & \multicolumn{3}{|c|}{ DVW th10 } & \multicolumn{3}{|c|}{ DVW distal } & \multicolumn{3}{|c|}{$2 \mathrm{TRD}$ th2 } \\
\hline & range & M & $\mathrm{n}$ & range & M & $\mathrm{n}$ & range & M & $\mathrm{n}$ & range & M & $\mathrm{n}$ \\
\hline D. triangulatus - early & $0.75-1.25$ & 1.04 & 19 & $0.65-1.15$ & 0.86 & 26 & $1.25-1.75$ & 1.5 & 15 & $1.3-1.9$ & 1.47 & 16 \\
\hline D. triangulatus - typical & $1.0-1.4$ & 1.14 & 11 & 1220 & 165 & 53 & $1.5-1.8$ & 1.65 & 13 & $1.35-2.2$ & - & - \\
\hline D. triangulatus - late & $0.9-1.3$ & 1.1 & 41 & $1.3-2.0$ & 1.03 & 53 & $1.3-2.0$ & 1.64 & 40 & $0.9-1.6$ & 1.15 & 33 \\
\hline D. major - early & $0.7-1.4$ & - & - & $1.4-2.05$ & 1.66 & 13 & $1.4-2.05$ & 1.66 & 13 & $1.4-1.6$ & - & - \\
\hline D. major-late & $0.6-1.3$ & - & - & $1.05-2.2$ & 1.5 & 10 & $1.05-2.2$ & 1.49 & 10 & $2.15(\mathrm{~s})$ & - & - \\
\hline D. pectinatus - early & & & & $1.3-1.7$ & 1.48 & 12 & $1.56-1.9$ & - & - & $0.75-1.3$ & 0.9 & 10 \\
\hline D. pectinatus - late & $0.9-1.15$ & 1.01 & 41 & $1.15-1.65$ & 1.38 & 31 & $1.45-1.8$ & 1.62 & 23 & $0.7-1.2$ & 0.82 & 22 \\
\hline D. campograptoides & $0.8-1.1$ & 0.92 & 10 & $0.75-1.0$ & 0.86 & 10 & $1.0-1.4$ & - & - & $1.2-1.6$ & - & - \\
\hline
\end{tabular}

Table 1. continued.

\begin{tabular}{|c|c|c|c|c|c|c|c|c|c|c|c|c|}
\hline \multirow{2}{*}{ Species and form } & \multicolumn{3}{|c|}{$2 \mathrm{TRD}$ th 3} & \multicolumn{3}{|c|}{$2 \mathrm{TRD}$ th 5} & \multicolumn{3}{|c|}{$2 \mathrm{TRD}$ th 10} & \multicolumn{3}{|c|}{ 2TRD distal } \\
\hline & range & M & $\mathrm{n}$ & range & M & $\mathrm{n}$ & range & M & $\mathrm{n}$ & range & M & $\mathrm{n}$ \\
\hline D. triangulatus - early & $1.05-1.65$ & 1.34 & 20 & $1.3-1.9$ & 1.49 & 20 & $1.8-2.1$ & 1.96 & 13 & $2.0-2.55$ & 2.18 & 11 \\
\hline D. triangulatus - typical & $1.2-1.95$ & - & - & $1.25-1.9$ & 1.56 & 15 & $1.7-2.0$ & 1.76 & 11 & $1.7-2.1$ & - & - \\
\hline D. triangulatus - late & $0.8-1.71$ & 1.07 & 45 & $0.7-1.5$ & 1.03 & 49 & $0.9-1.6$ & 1.2 & 41 & $1.6-2.25$ & 1.81 & 19 \\
\hline D. major - early & $1.1-1.52$ & - & - & $1.15-1.7$ & 1.33 & 10 & $12-1.8$ & 1.46 & 21 & $1.25-2.1$ & 1.65 & 20 \\
\hline D. major - late & $1.6-2.6$ & - & - & $1.6-2.54$ & - & - & & & & & & \\
\hline D. pectinatus - early & $0.7-1.25$ & 0.89 & 10 & 0612 & 001 & 16 & 0015 & 12 & 20 & 150 & 185 & 20 \\
\hline D. pectinatus - late & $0.6-1.0$ & 0.78 & 29 & $0.0-1.2$ & 0.91 & 40 & $0.9-1.5$ & 1.2 & (3) & $1.0-2.2$ & $1.0 J$ & 20 \\
\hline D. campograptoides & $1.1-1.6$ & - & - & $1.25-1.8$ & 1.48 & 11 & $1.4-1.93$ & - & - & $1.7-2.1$ & - & - \\
\hline
\end{tabular}

$0.18 \mathrm{~mm}$ wide at the aperture. The apex of the sicula attains the level of the base of the dorsal metathecal wall of th1 or up to $0.2 \mathrm{~mm}$ below. The thecae are markedly biform. Nine to twelve proximal thecae are sub-rastritiform with slightly hooked apertures furnished with small lateral processes. The first theca, which possesses a tapering metatheca,

Figure 6. A, H-Demirastrites campograptoides sp. nov.; A-PŠ 3991, sample HT150-160; H - PŠ3988b, sample HT160-170. • B, C, J - Demirastrites major (Elles \& Wood), late morphotype of the species; B - PŠ 4032, sample HT90-100; C - PŠ 4028, sample HT90-100, twisted sub-proximal thecae showing thecal apertures transversely extended into prominent lateral processes; J - PŠ 3925, sample HT90-100. • E - Demirastrites major (Elles \& Wood), early morphotype, PŠ 4027, sample HT100-110. • D, G, I - Demirastrites pectinatus (Richter), late morphotype; D - PŠ 4200, sample HT120-130; G - PŠ 3996, sample HT110-120; I - PŠ 3992, sample HT110-120. • F - Demirastrites pectinatus (Richter), early morphotype; PŠ 4234, sample HT130-140. All specimens from Hlásná Třebaň. Figures A-B, D, F-I, ×5; figures C-E, J, ×10; scale bars represent 1 mm. 


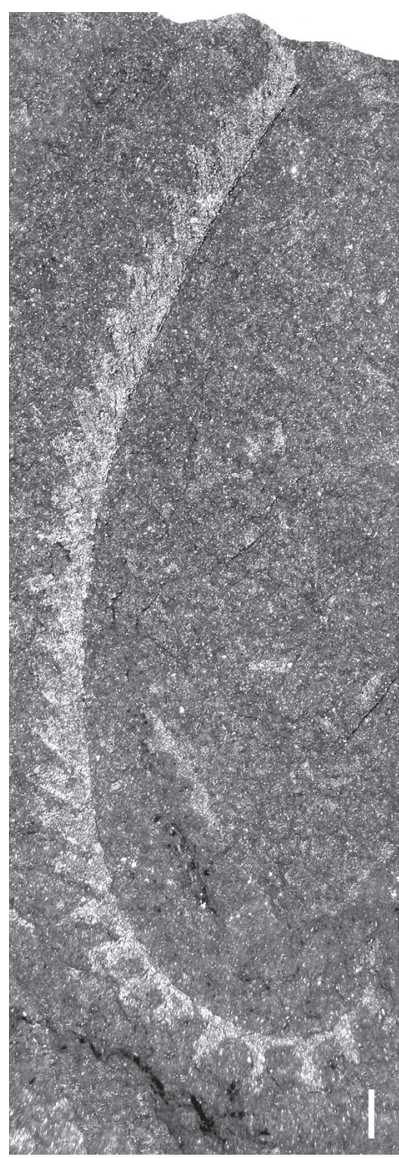

A

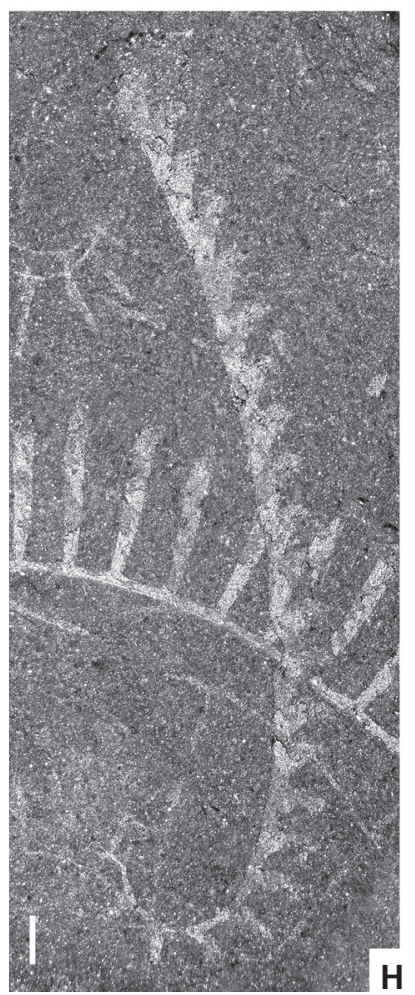

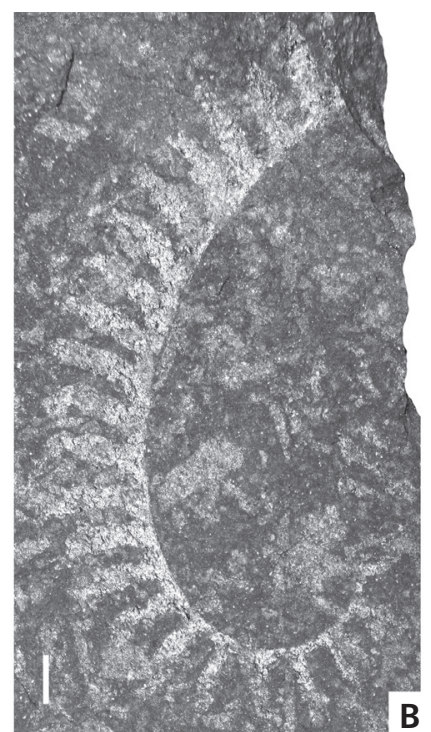
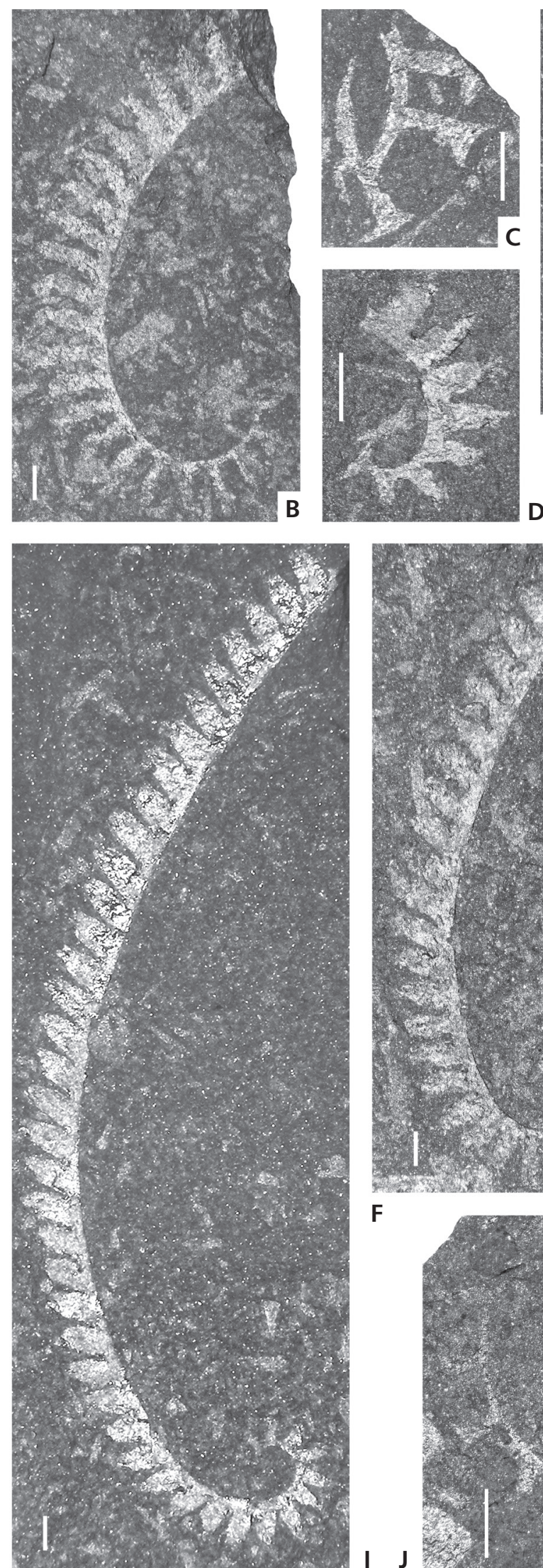

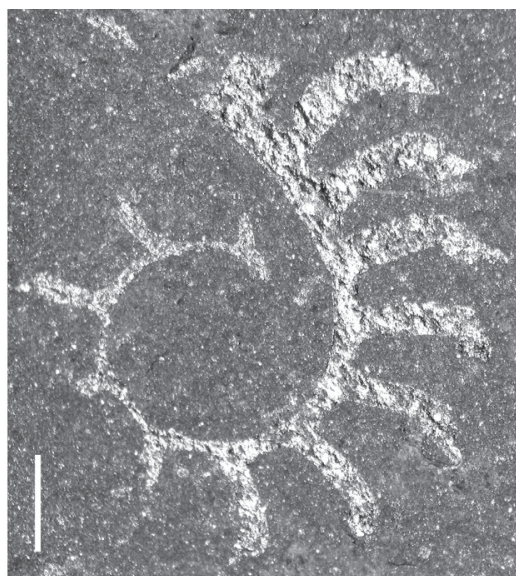

E
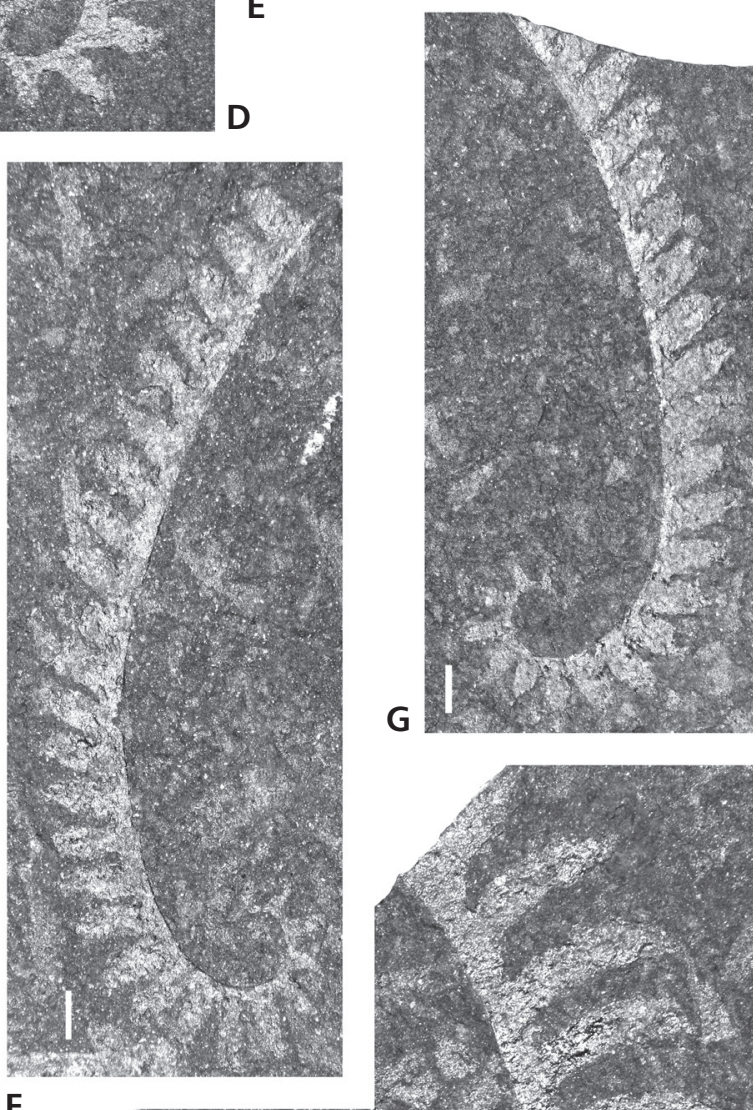

F

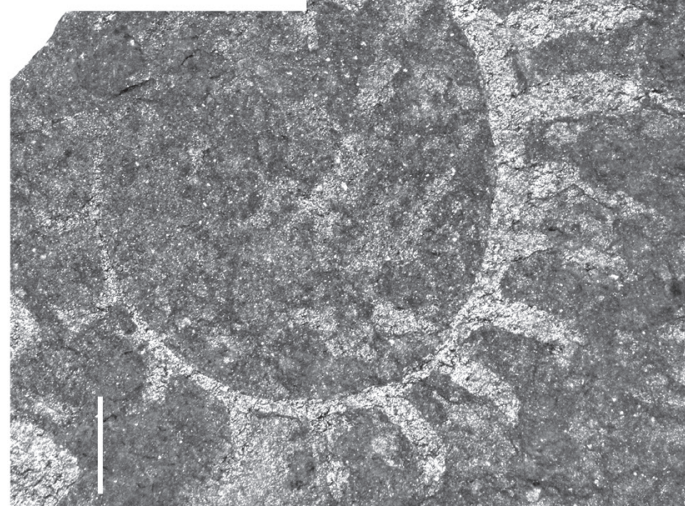


buds $0.2-0.35 \mathrm{~mm}$ above the sicular aperture. The prothecae are $0.4-0.7 \mathrm{~mm}$ long in the five most proximal thecae, and prothecal width increases from $0.08 \mathrm{~mm}$ at th2 to nearly $0.2 \mathrm{~mm}$ at th5. The proximal metathecae are slightly narrowing tubes $c a 0.2 \mathrm{~mm}$ wide at th2 and $0.2-0.3 \mathrm{~mm}$ wide at th 5 , all inclined at a mean angle of $78^{\circ}$. Subsequent thecae become more inclined, more triangular, and more markedly hooked. Prothecal length decreases to $0.2-0.5 \mathrm{~mm}$ at th 10 , whereas prothecal width increases to $0.25-0.35 \mathrm{~mm}$. Distal metathecae attain a mid-point width of $0.3-0.45 \mathrm{~mm}$. Distal thecae are triangular with no distinct prothecal tube, inclined at $40-55^{\circ}$ to the rhabdosomal axis, and terminated by rounded, weak hooks with proximally facing apertures and apparently short lateral apertural processes.

Discussion. - This uncommon species was assigned to Demirastrites raitzhainensis (Eisel) by Štorch et al. (2018) due to its relatively strongly inclined, blunt and rounded distal thecae, which are almost campograptid in shape. Monograptus raitzhainensis was named (as Monograptus convolutus var. Raitzhainiensis) but neither described nor figured by Eisel (1899) and was first figured but still not described by Eisel (1908). Close examination of the figures and description of the material subsequently described by Törnquist (1907) and Eisel (1912) reveals that the distinctive appearance of this form is a preservational artefact, with distal thecae heavily deformed by tectonic strain, a possiblity discussed by Törnqust (1907). In addition, specimens identified and figured as M. raitzhainensis by Elles \& Wood (1913) were assigned to M. separatus separatus and M. separatus triangulatus by Sudbury (1958) and, therefore, to Demirastrites triangulatus in the sense of the present paper.

Demirastrites campograptoides is distinguished from other species of Demirastrites primarily by its more highly inclined distal thecae, lower distal DVW, and generally lower distal 2TRD. In addition, the lateral processes appear to be less prominent on the distal thecae of D. campograptoides compared with the other taxa described here, resulting in the appearance of simpler thecal hooks upon flattening. In contrast, the presence of both lateral thecal apertural processes and sub-rastritiform proximal thecae distinguish this species from species of Campograptus. In addition, species of Campograptus are generally characterized by metathecae that are relatively shorter compared to their width.

\section{Demirastrites major (Elles \& Wood, 1913)}

Figures 6B, C, E, J; 7A-L

1913 Monograptus triangulatus var. major, var. nov.; Elles \& Wood, p. 472 (pars), pl. 47, fig. 5c (?5d, non 5a, b), text-fig. 328 b (non 328a).
1958 Monograptus separatus major Elles \& Wood. Sudbury, p. 506, text-fig. 10.

? 1963 Monograptus triangulatus var. major E. \& W. Willefert, pp. 45, 46, pl. 2, fig. 2, text-fig. 73.

? 1967 Demirastrites triangulatus major (Elles \& Wood). Obut et al., p. 128, pl. 18, figs 3, 4.

1970 Monograptus triangulatus major Elles \& Wood. Rickards, p. 81, text-fig. 18-2.

1975 Monograptus triangulatus major Elles \& Wood. Hutt, pp. 110, 111, pl. 20, fig. 1.

non 1995 Demirastrites triangulatus major (Elles et Wood). Li, p. 272, pl. 29, fig. 6.

2015 Demirastrites major (Elles \& Wood). - Štorch, p. 885, figs $17 \mathrm{r}, 18 \mathrm{e}$.

2018 Demirastrites major (Elles \& Wood). - Štorch et al., p. 371, fig. 8c, o.

Lectotype. - Designated by Přibyl \& Münch (1942, p. 7), new designation by Bulman (1957, p. 314), see also Sudbury (1958, p. 507). Specimen no. GSM26326 from the Rheidol Gorge, Wales, figured by Elles \& Wood (1913, text-fig. 328b).

Material. - Twenty-nine flattened, more-or-less complete rhabdosomes from the lower and middle pectinatus Biozone of the Hlásná Třebaň section and four incomplete rhabdosomes from Všeradice.

Diagnosis. - Rhabdosome dorsally curved, coiled in the proximal part, attaining a width of $2.0-2.3 \mathrm{~mm}$ by th $18-20$. Proximal thecae slender, rastritiform to sub-rastritiform, commonly slightly ventrally curved. Distal thecae subrastritiform, parallel-sided, slightly ventrally curved, numbering $10-12$ in $10 \mathrm{~mm}$. Narrow, proximally facing thecal apertures transversely extended into prominent lateral processes.

Description. - The rhabdosome is arcuate, with dorsal curvature that is more tightly coiled and probably slightly helicoidal in the proximal part. It is curved through more than $300^{\circ}$ within 10 proximal thecae, crossing the mesial part of the rhabdosome in the stratigraphically lowest specimens (early form) from the lower pectinatus Biozone. In stratigraphically higher specimens (late form), however, the proximal end is more protracted and less strongly coiled (Figs 6J; 7B, C, F). Mature rhabdosomes attain more than $30 \mathrm{~mm}$ in length. The sicula and th1 have not been identified with certainty in the present specimens. The most proximal preserved thecae (likely th2-th5) are slender and rastritiform to sub-rastritiform (slightly ventrally curved), and the prothecal tubes of the late form are of the same length or longer than the metathecae $[0.6-1.2 \mathrm{~mm}$ at th3, $0.5-1.15 \mathrm{~mm}(\mathrm{M}=0.65 \mathrm{~mm}, \mathrm{n}=18)$ at th5]. The prothecal width varies between 0.1 and $0.2 \mathrm{~mm}$ at th5. 


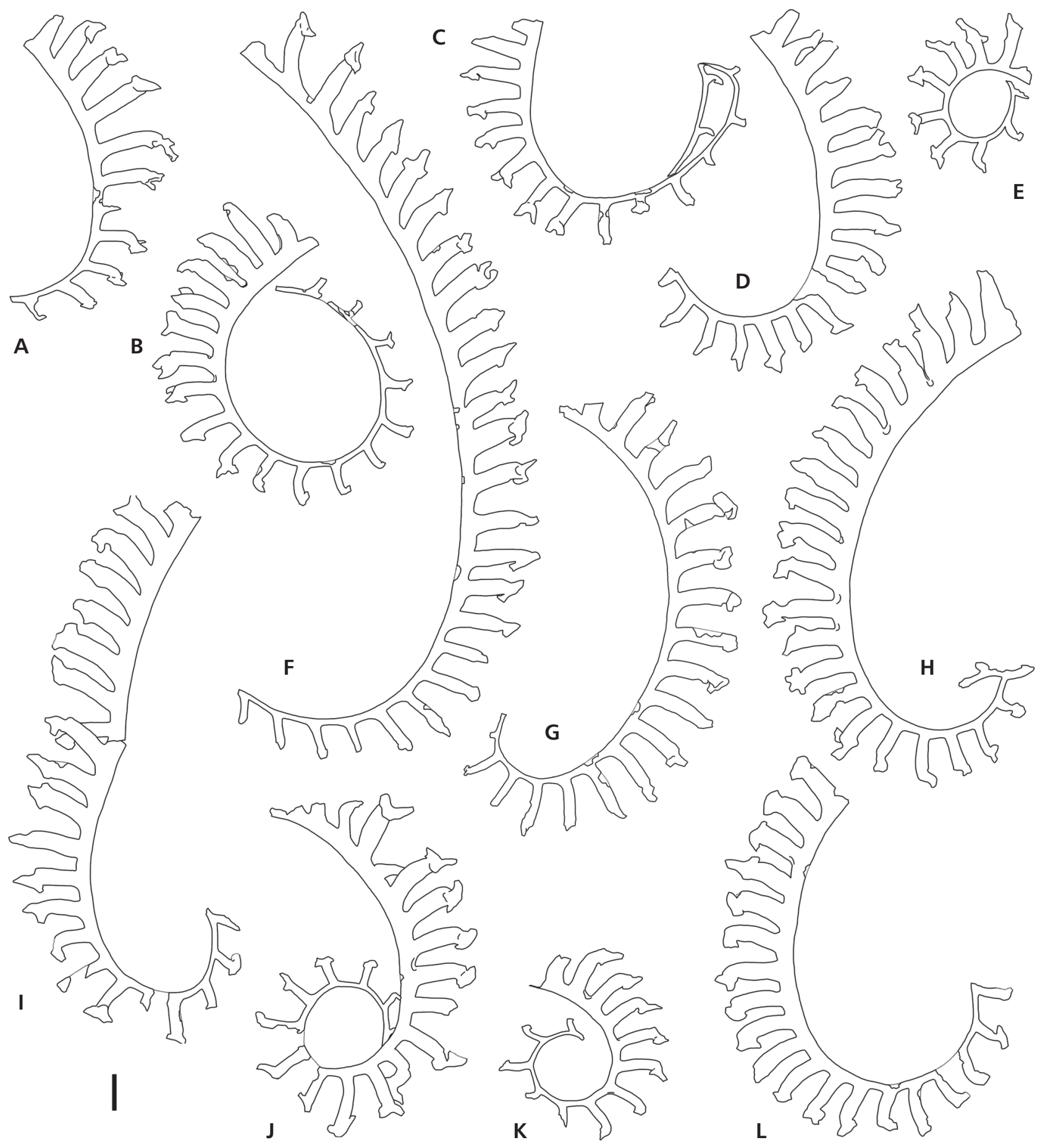

Figure 7. Demirastrites major (Elles \& Wood); A - PŠ 4055, sample HT70-80; B - PŠ 4070, sample HT80-90; C - PŠ 4064, sample HT80-90; D - PŠ 4029, sample HT90-100; E - PŠ 4031, sample HT90-100; F - PŠ 4056, sample HT70-80; G - PŠ 4300; H - PŠ 4032, sample HT90-100; I - PŠ 4040, sample HT90-100; J - PŠ 4022, sample HT100-110; K - PŠ 4027, sample HT100-110; L - PŠ 4025, sample HT100-110. All specimens from Hlásná Třebaň except for $\mathrm{G}$ from the lowermost pectinatus Biozone of Všeradice. Figures A-C, F and ?G illustrate the late morphotype of the species; figures D-E, $\mathrm{H}-\mathrm{L}$ exhibit the early morphotype. All figures $\times 6$, scale bar represents $1 \mathrm{~mm}$.

Metathecal tubes of the proximal thecae are straight or very slightly ventrally curved, $c a 0.15 \mathrm{~mm}$ wide at th 2 and $0.15-0.35 \mathrm{~mm}$ at th 5 , inclined at an angle of $50-75^{\circ}$ at th2 and $65-90^{\circ}$ at th5. Mesial thecae are more densely spaced, with $0.3-0.75 \mathrm{~mm}$ long and $0.15-0.3 \mathrm{~mm}$ wide prothecae. The parallel-sided, tubular metathecae are $1.2-2.2 \mathrm{~mm}$ $(\mathrm{M}=1.6 \mathrm{~mm}, \mathrm{n}=23)$ high and $0.25-0.45 \mathrm{~mm}$ wide at th10 and are most commonly slightly ventrally curved. The 
maximum DVW of the rhabdosome (Tab. 1) is attained by th18-20. Distal thecae most commonly possess short, $0.3-0.5 \mathrm{~mm}$ wide, distinct prothecal tubes, concave in ventral outline, and with high, generally parallel-sided to slightly tapering, ventrally curved metathecae that are $0.4-0.55 \mathrm{~mm}$ wide, and only slightly inclined $\left(70-90^{\circ}\right)$ to the rhabdosomal axis. The thecal apertures possess fully developed dorsal hoods furnished with a pair of lateral processes that are best seen when twisted into a facing profile (Figs 6C; 7E, J, L). The original position of the lateral apertural processes (described as lateral horns by some earlier authors) must have been approximately perpendicular to the axial plane of the theca. The lateral processes are small, $c a .0 .2 \mathrm{~mm}$ long in the proximal thecae (up to th5), and became more prominent, $0.3-0.4 \mathrm{~mm}$ long, in the mesial and distal thecae. The most common preservation of the thecal apertures, however, exhibits just one visible lateral process folded across the dorsal margin of the apertural hood.

Discussion. - Demirastrites major can be distinguished from other species of Demirastrites by having generally parallel-sided, slightly ventrally curved metathecae distally, which are separated by short, distinct prothecal tubes. In addition, the distal DVW is more than $2.0 \mathrm{~mm}$ (normally 2.2 to $2.3 \mathrm{~mm}$ ) beginning at about th18-20. The thecal apertures are furnished with particularly prominent lateral processes. The proximal part of the rhabdosome is rather protracted and less strongly coiled in the late form, with metathecae shorter and more widely spaced than those in other demirastritids of the triangulatus group. The early form of this species, which occurs in the lower pectinatus Biozone at Hlásná Třebaň (Figs 6E; 7E, J, K), possesses a generally shorter and more tightly coiled proximal part with shorter, less widely spaced thecae, resembling those of the stratigraphically highest forms of $D$. triangulatus. The same morphology has been found in specimens from Všeradice, which were also collected from the lower pectinatus Biozone. Specimens from higher parts of the pectinatus Biozone (Figs 6B, $\mathrm{J} ; 7 \mathrm{~A}-\mathrm{C}, \mathrm{F}$ ) exhibit progressive straightening of the proximal part and further prothecal elongation, combined with shorter proximal metathecae, resulting in a more gradual distal increase in DVW.

Sudbury (1958) reported D. major as "fairly certain[ly]" from the magnus Band of the Rheidol Gorge section. The magnus Band at Rheidol Gorge occurs within the upper part of the range of "Monograptus fimbriatus" (=D. pectinatus) and, therefore, probably corresponds with the middle to upper part of the pectinatus Biozone as recognized in the Prague Synform.

"Monograptus triangulatus var. major", identified by Willefert (1963) from central Morocco, possesses long and relatively densely spaced thecae in its tightly enrolled proximal part. The figured specimen may be tentatively assigned to either the early form of $D$. major or the late form of $D$. triangulatus (see below). Specimens from the Kolyma Basin of northeastern Siberia, assigned to D. triangulatus major by Obut et al. (1967), possess a significantly wider rhabdosome, with a DVW of $3.0-3.5 \mathrm{~mm}$ attained $10 \mathrm{~mm}$ from the proximal end, and widely spaced distal thecae, which number 7-9 in $10 \mathrm{~mm}$. Those specimens came from a single locality and appear to be affected by tectonic strain, so their identity is uncertain. The specimen identified as Demirastrites triangulatus major figured by Li (1995) from Yichang, China, is a distal fragment of Lituigraptus with typical, ventrally directed, wedge-shaped thecal apertural processes.

\section{Demirastrites pectinatus (Richter, 1853)}

Figures 6D, F, G, I; 8A-R

1853 Monograptus pectinatus; Richter (pars), p. 461, pl. 12, fig. 26 (non 27).

1868 Graptolites fimbriatus n. sp. - Nicholson, p. 536, pl. 20, fig. 5, ?figs 3, 4.

1897 Monograptus fimbriatus Nich. - Perner (pars), pp. 28,29 , pl. 11, fig. 39 , pl. 12, figs $13, ? 18$, pl. 13, figs 21-23 (non 25).

1899 Monograptus fimbriatus Nicholson. - Törnquist, p. 18, pl. 3, fig. 24.

1912 Demirastrites pectinatus, Richter. - Eisel (pars), p. 39, pl. 3, figs 16, 18-20 (non 17).

1913 Monograptus fimbriatus (Nicholson). - Elles \& Wood (pars), p. 482, pl. 48, figs 4a, d (non b, c), text-figs 338a, b, ?(c, d).

1942 Demirastrites pectinatus pectinatus (Richter). - Přibyl \& Münch, pp. 8, 9, pl. 1, fig. 6, text-fig. 1-4, 1-5.

1958 Monograptus separatus fimbriatus (Nicholson). Sudbury, p. 499, pl. 19, figs 40-51, text-fig. 5.

1963 Monograptus fimbriatus (Nicholson). - Willefert, pp. 43, 44, pl. 2, fig. 1, text-fig. 69.

non 1968 Demirastrites pectinatus pectinatus (Richter). - Obut et al., p. 108, pl. 29, figs 4-6, pl. 30, figs 1, 2.

1970 Monograptus triangulatus fimbriatus (Nicholson). Rickards, p. 82, pl. 7, fig. 4, text-fig. 17-2.

1971 Monograptus (Demirastrites) pectinatus (Richter). Schauer, pp. 77, 78, pl. 26, fig. 1, pl. 27, fig. 1.

1975 Monograptus triangulatus fimbriatus (Nicholson). - Hutt, p. 110, pl. 20, fig. 5, pl. 21, figs 5, 6, pl. 22, figs 3, 4, 6, 7, text-fig. 17-6.

1975 Monograptus pectinatus Richter.-Bjerreskov, pp. 78, 79 , pl. 11, fig. f, text-fig. $23 \mathrm{~d}$.

? 1982 Monograptus triangulatus fimbriatus (Nicholson). Lenz, p. 116, figs 91, m, q, 30b, g.

1989 Monograptus pectinatus pectinatus Richter. Melchin, p. 1738, fig. 9x.

2003 Demirastrites pectinatus (Richter). - Loydell et al., p. 209 , fig. 4 r. 


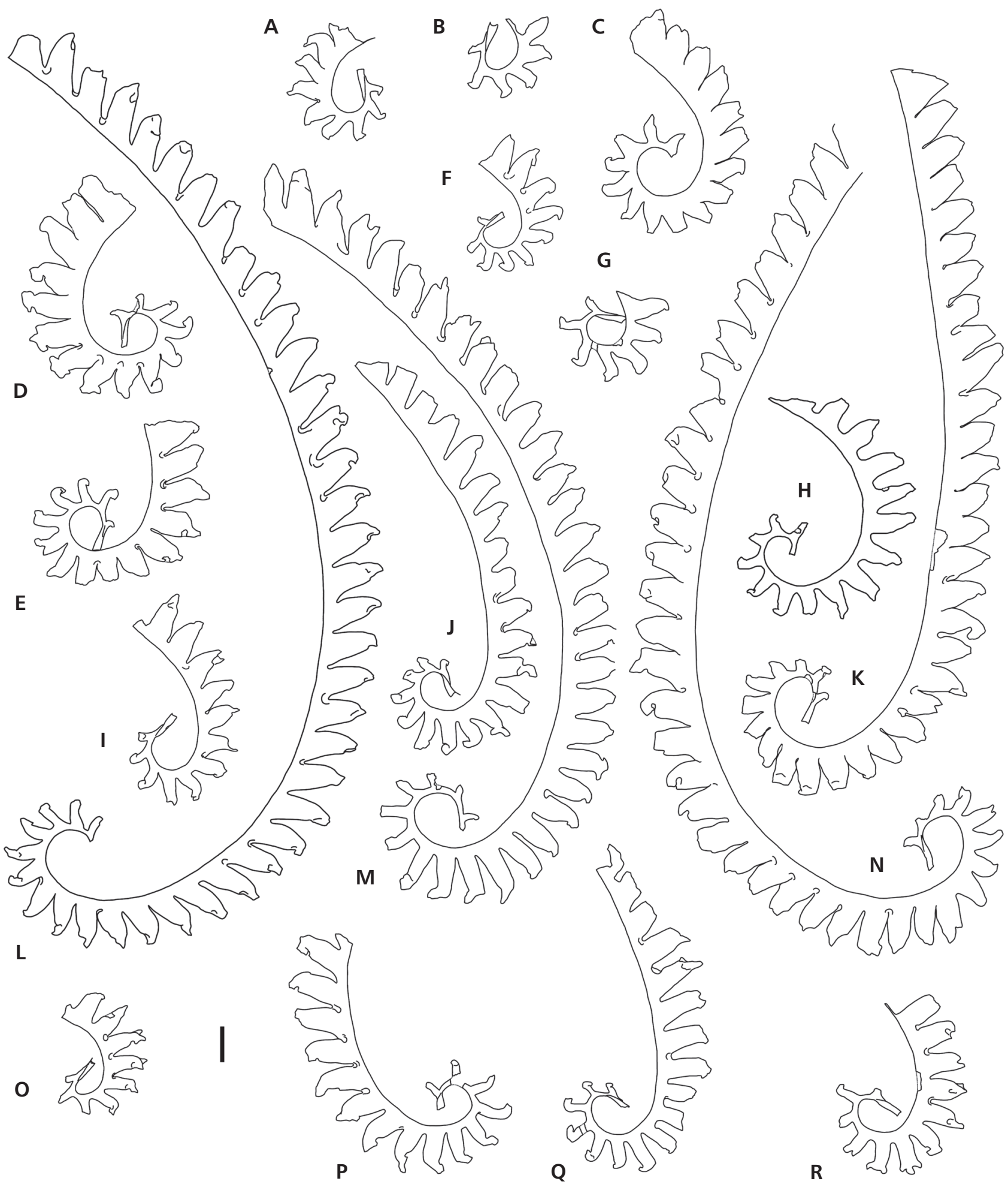

Figure 8. Demirastrites pectinatus (Richter); A - PŠ 4049, sample HT30-40; B - PŠ 4309, sample HT10-20; C - PŠ 4310, sample HT10-20; D - PŠ 4037, sample HT90-100; E - PŠ 4073, sample HT100-110; F - PŠ 4000, sample HT110-120; G - PŠ 4067b, sample HT80-90; H - ROM 45971, sample CM - 0-2, loose collection approximately equivalent to MCM2-98, 43-45 m, see Melchin et al. (2017, fig. 3); I-PŠ 4003, sample HT110-120; J - PŠ 4201, sample HT120-130; K - PŠ 4071, sample HT80-90; L - PŠ 4021, sample HT100-110; M - PŠ 4189, sample HT120-130; N - PŠ 4057, sample HT70-80; O - PŠ 4200, sample HT120-130; P - PŠ 3989, sample HT110-120; Q - PŠ 4195, sample HT120-130; R - PŠ 3997, sample HT110-120. All specimens from Hlásná Třebaň except for H from Cape Manning section, Cornwallis Island, Arctic Canada. Figures A-G, ?H, I, K-L and N-P represent the late morphotype of the species; figures J, M and Q, R represent the early morphotype. All figures $\times 6$, scale bar represents $1 \mathrm{~mm}$. 
2009 Demirastrites pectinatus. - Piçarra et al., p. 46, fig. $5 \mathrm{~b}$.

2009 Demirastrites pectinatus (Richter). - Štorch \& Kraft, p. 62 , figs $7 \mathrm{~b}, 8 \mathrm{c}$, p. $68,11 \mathrm{j}$.

2017 Demirastrites pectinatus (Richter). - Loydell \& Aung, p. 12 , fig. $8 \mathrm{~g}$.

2017 Demirastrites pectinatus (Richter). - Loydell et al., p. 147 , fig. $12 \mathrm{j}$.

2018 Demirastrites pectinatus (Richter). - Štorch et al., p. 371 , fig. $8 \mathrm{k}$, p.

2018 Monograptus triangulatus fimbriatus (Nicholson). Wilkinson, folio 3.32 .

Holotype. - By monotypy. Specimen no. BGR X 10486 from Rothenbach bei Saalfeld, Thuringia, figured by Richter (1853, pl. 12, fig. 26).

Material. - Forty-eight flattened, mostly complete rhabdosomes from the pectinatus Biozone of the Hlásná Třebaň section and fourteen rhabdosomes from the Černošice section.

Diagnosis. - Rhabdosome with proximally accentuated dorsal curvature. Small sicula with apex attaining up to the level of the dorsal wall of the first metatheca. Three to rarely five proximal thecae sub-rastritiform, one or two somewhat axially elongated. Subsequent thecae become robust, bluntly triangular in outline. Metathecae weakly hooked, slightly more strongly hooked proximally, separated by a very narrow interspace or tightly appressed in flattened specimens. Narrow proximally facing thecal apertures furnished with short lateral processes.

Description. - The rhabdosome is strongly dorsally curved proximally, more weakly distally and the maximum length is at least $50 \mathrm{~mm}$. The proximal dorsal curvature ranges from $255^{\circ}$ to $340^{\circ}\left(\mathrm{M}=298^{\circ}, \mathrm{n}=25\right)$ within the first 10 thecae. The sicula is conical, short $(0.7-1.0 \mathrm{~mm})$, straight or gently ventrally curved, and $0.17-0.22 \mathrm{~mm}$ wide across its concave aperture, which possesses a short, narrow virgella. The sicular apex typically attains the level of the base of the dorsal metathecal wall of th 1 or slightly $(0.1 \mathrm{~mm})$ below. The three or four (rarely five) most proximal thecae are sub-rastritiform and axially elongated, with short, slightly widening prothecal tubes and triangular metathecae, inclined at a relatively low mean angle of $71^{\circ}$ at th2 $(\mathrm{n}=32)$ and $79^{\circ}$ at th $5(\mathrm{n}=44)$. The first theca is $0.75-1.0 \mathrm{~mm}$ long from its point of origin to the base of the dorsal wall of the metatheca. Its slender, $0.3-0.55 \mathrm{~mm}$ long protheca buds $0.15-0.4 \mathrm{~mm}$ above the sicular aperture. The protheca of th2 is $0.07-0.18 \mathrm{~mm}$ wide at its base, and subsequent prothecae widen through $0.15-0.32 \mathrm{~mm}$ at th5, and to $0.25-0.5 \mathrm{~mm}$ at th 10 . The metathecae are $0.17-0.4 \mathrm{~mm}$ wide at the mid-point of their height at th2, $0.3-0.48 \mathrm{~mm}$ at th 5 and $0.5-0.75 \mathrm{~mm}$ at th 10 . Mesial and distal thecae become more robust and bluntly triangular in outline, inclined at a mean angle of $78^{\circ}$ at th $10(\mathrm{n}=42)$ and $70^{\circ}$ distally $(\mathrm{n}=31)$. The distal thecae are $0.55-0.85 \mathrm{~mm}$ wide at the mid-point of their height. The prothecae are $0.3-0.6 \mathrm{~mm}$ wide and the prothecal tubes are entirely reduced in the mesial and distal thecae, leaving a very narrow interspace between the dorsal wall of one metatheca and the ventral wall of the subsequent metatheca. The thecae are weakly hooked, although slightly more strongly hooked proximally; the thecal apertures face proximally and are furnished with rather short (max. $0.2 \mathrm{~mm}$ ) lateral processes that are commonly folded across the dorsal apertural hood to form a somewhat pointed termination of the generally triangular theca.

Discussion. - Demirastrites pectinatus (Richter, 1853) may be distinguished from most other triangulate monograptids by the fact that it possesses no rastritiform thecae and very few (usually four or less) sub-rastritiform thecae. Its most proximal thecae are axially elongated with triangular metathecae. The early form of Demirastrites pectinatus corresponds in thecal shape, DVW, thecal spacing and all other relevant characters to its junior synonym, Monograptus triangulatus fimbriatus (Nicholson, 1868), including the neotype of the latter species, which was designated by Sudbury (1958, p. 500). All specimens reported from the Yukon Territory, Canada (Lenz, 1982 and authors' collections) are small rhabdosomes with about 10 thecae or less, and the maximum dorso-ventral width of these rhabdosomes is only $1.3 \mathrm{~mm}$, which is less than that measured at the corresponding theca in European populations or in those from Arctic Canada (Melchin 1989). In addition, the thecal spacing is closer (2TRD $1.1-1.35 \mathrm{~mm}$, rarely up to $1.6 \mathrm{~mm}$ ) and the angle of thecal inclination is also lower than that in European specimens. As a result the Yukon specimens are only questionably regarded as belonging to this species.

Regarding the form of the apertural processes, we speculate that these processes were laterally projected from both sides of the dorsal apertural hood based on details preserved in some flattened rhabdosomes (Fig. 8D, K, O, R). Somewhat more prominent dorsal apertural processes have been observed in early populations referred to D. pectinatus.

Demirastrites pectinatus can be readily distinguished from ?Demirastrites similis (Elles \& Wood, 1913) by the more protracted proximal end of the former, which possesses a relatively low, triangular and axially elongated th1, and its sicula attains about the level of the first metatheca followed by several sub-rastritiform thecae. The proximal end of ?D. similis is more compressed in appearance, with a rather short and high th1 and a sicula 
that attains the level of the metatheca of th2. In addition, ?D. similis appears to be lacking in sub-rastritiform proximal thecae after th1. As a result, we have only questionably placed that species in Demirastrites.

Specimens from the Norilsk Basin of western Siberia assigned to $D$. pectinatus pectinatus by Obut et al. (1968) attain a lesser maximum width $(1.2-1.4 \mathrm{~mm})$, and possess more broadly triangular thecae of almost campograptid appearance, inclined at $45^{\circ}$ to the rhabdosome and terminated by apertural hooks composed, for the most part, of the dorsal thecal wall. Thecal apertures face proximally and probably lack the typical transversal extension into lateral processes. Proximal thecae are axially elongated and low-triangular in profile. Specimens have been reported from the lower part of the triangulatus Biozone, which contrasts with the range of $D$. pectinatus in European sections. These Siberian specimens closely resemble material assigned to Demirastrites $\mathrm{cf}$. triangulatus by Chen (1984) from southern Shaanxi and southern Sichuan provinces in China and specimens collected by the present authors from the "triangulatus Biozone" of the Yuxian section in southeastern Sichuan.

\section{Demirastrites triangulatus (Harkness, 1851)}

Figures 9A-X; 10A-I; 11

1851 Rastrites triangulatus; Harkness (pars), p. 59, fig. 3a, b (non $\mathrm{c}, \mathrm{d})$.

1897 Monograptus triangulatus Harkn. - Perner, p. 27, pl. 12, fig. 16, (?fig. 30), text-fig. 12.

1899 Monograptus triangulatus Harkness, var. Raitzhainiensis Eisel, p. 7. [nomen nudum]

1899 Monograptus triangulatus Harkness. - Törnquist, pp. 19, 20, pl. 3, figs 25-28, pl. 4, figs 1, 2.

1907 Monograptus triangulatus Harkness, var. Raitzhainiensis Eisel. - Törnquist, p. 17, pl. 3, figs 2-4.

1908 Monograptus triangulatus var. Raitzhainiensis. Eisel, p. 220, fig. 11.

1912 Demirastrites triangulatus, Harkness. - Eisel, pp. 36, 37, pl. 3, figs 8-12, 14, 15, ?(6, 7, 13).

1913 Monograptus triangulatus (Harkness). - Elles \& Wood (pars), p. 471, pl. 47, figs 4a, c, d (non b, e), text-fig. $327 \mathrm{~b}$ (non a, c).

1913 Monograptus raitzhainiensis (Eisel). - Elles \& Wood (pars), pp. 473, 474, pl. 48, fig. 3a (non b, c), text-fig. 329a (non 329b).

1942 Demirastrites triangulatus (Harkness). - Přibyl \& Münch (pars), p. 3, pl. 1, figs 1-5, text-fig. 1-1, 1-2, (non 1-3).

1958 Monograptus separatus triangulatus (Harkness). Sudbury, pp. 503-506, pl. 20, figs 52-63 (see for further synonymy).

1958 Monograptus separatus separatus var. nov. - Sudbury, pp. 496-499, pl. 19, figs 33-39.
1963 Monograptus triangulatus (Harkness). - Willefert, p. 45 , pl. 2 , fig. 5 , text-fig. 72 .

? 1963 Monograptus triangulatus var. major E. \& W. Willefert, pp. 45, 46, pl. 2, fig. 2, text-fig. 73.

? 1965 Demirastrites triangulatus (Harkness). - Obut et al., pp. 86, 87, pl. 17, figs 1-3.

? 1968 Demirastrites triangulatus triangulatus (Harkness). Obut et al., pp. 106-108, pl. 27, figs 3-5, pl. 28, figs $1-5$, pl. 29, figs $1-3$.

1970 Monograptus triangulatus triangulatus (Harkness). Rickards, pp. 80, 81, text-fig. 18-1.

1970 Monograptus triangulatus separatus Sudbury. Rickards (pars), p. 81, text-fig. 13-17, text-fig. 17-4 (non 17-3).

1971 Monograptus (Demirastrites) triangulatus (Harkness). - Schauer, p. 78, pl. 26, figs 9-11, pl. 27, fig. 3.

1975 Monograptus triangulatus triangulatus (Harkness).Hutt, pp. 109, 110, pl. 19, figs 1, 2, pl. 20, figs 2, 7.

1975 Monograptus triangulatus separatus Sudbury. - Hutt, p. 111, pl. 21, fig. 1.

1975 Monograptus triangulatus triangulatus (Harkness). Bjerreskov, pp. 77, 78, text-fig. 23a, pl. 11, fig. e.

? 1978 Demirastrites triangulatus (Harkness). - Chen \& Lin, pp. 65 , 66, pl. 15 , figs $5-8$, text-fig. $17 \mathrm{~b}$.

? 1982 Demirastrites triangulatus (Harkness). - Anhui Geological Survey Team, p. 114, pl. 28, figs 9, 10.

? 1995 Demirastrites triangulatus (Harkness). - Li (pars), p. 271, pl. 29, fig. ?5 (non 3, 4).

2000 Monograptus triangulatus separatus Sudbury. Sudbury \& Hutt, folio 1.64

2003 “Demirastrites" triangulatus (Harkness). - Loydell et al., p. 209, fig. 4h.

2007 Monograptus triangulatus triangulatus (Harkness). Zalasiewicz, folio 2.92.

2009 Demirastrites triangulatus. - Piçarra et al., p. 46, fig. 5a.

2015 Demirastrites triangulatus (Harkness). - Štorch, pp. 884 , 885, figs $16 \mathrm{a}, \mathrm{b}, 17 \mathrm{f}, \mathrm{h}, \mathrm{m}, \mathrm{n}, 18 \mathrm{~b}$, c.

2017 Demirastrites triangulatus (Harkness). - Loydell \& Aung, p. 13, fig. 9e.

2017 Demirastrites triangulatus (Harkness). - Loydell et al., p. 151, fig. $14 \mathrm{~h}$.

2018 Demirastrites triangulatus (Harkness). - Štorch et al., p. 367 , fig. 6 , p. 369 , fig. $71-n$.

Lectotype. - Designated by Přibyl \& Münch (1942, p. 4). Specimen no. GSM6941 from Frenchland Burn, Dumfriesshire, Scotland, figured by Harkness (1851, pl. 1, fig. 3a, ?b).

Material. - One hundred and nineteen flattened, more-orless complete measured rhabdosomes from the triangulatus Biozone and lowermost pectinatus Biozone of the Hlásná Třeban̆ section and twelve rhabdosomes from Všeradice, 
eight rhabdosomes from Karlík, ten rhabdosomes from El Pintado (Spain), and minor supplementary material from the Estana section (Spanish Pyrenees) and the Oberbuchach section (Carnic Alps).

Diagnosis. - Rhabdosome arcuate in distal part, hookshaped to dorsally coiled in proximal part. Distal rhabdosome width ranges commonly from $1.5-1.65 \mathrm{~mm}$, rarely $1.3 \mathrm{~mm}$ to $2.0 \mathrm{~mm}$. Proximal thecae rastritiform to sub-rastritiform, first one or two thecae axially elongated. Distal thecae, numbering 9-11 in $10 \mathrm{~mm}$, are either subrastritiform or, more commonly, high-triangular, but always separated by significant interspaces. Thecae terminated by proximally facing apertures transversely extended into a pair of lateral processes.

Description. - The present specimens of $D$. triangulatus show significant morphological changes in several characters between the lowest collections at the base of the triangulatus Biozone to the stratigraphically highest specimens from the lowermost pectinatus Biozone. Based on these variations in form we recognize three distinct morphotypes: the early form (ranges from HT200-207 to HT185-190 m); the typical form (which most closely resembles specimens assigned to this species in other parts of Europe and ranges from HT190-200 to HT170-180 m); and the late form (ranges from HT170-180 to HT120-130 m). Rhabdosomes from the lower part of the triangulatus Biozone, including both the early form and the typical form, are hook-shaped, tightly dorsally curved in the proximal part and moderately arcuate distally. The proximal end is curved through $250-300^{\circ}$ (exceptionally $340^{\circ}$ ) up to the level of th 10 . The proximal end, which may have been helical in form, is more tightly coiled in the late forms, curving through a mean angle of $340^{\circ}(\mathrm{n}=27)$ between th1 and th10.

The sicula is $0.75-1.05 \mathrm{~mm}$ long, $0.16-0.23 \mathrm{~mm}$ wide at the aperture, with its apex attaining $0-0.5 \mathrm{~mm}$ below the level of dorsal wall of the first metatheca. In the late form the sicula tends to be slightly shorter but its apex attains a relatively higher level relative to th 1 . In the early and typical forms the first two proximal thecae are axially elongated with, on average, relatively shorter and more inclined metathecae, than in the late form, which normally shows only one axially elongate theca proximally.
In the early form, all or most of the thecae from th3 onward are sub-rastritiform, with a distinct, widening prothecal tube and straight to slightly ventrally curved, weakly tapering metathecae. Only a few specimens possess distal thecae that are high-triangulate (e.g. Figs 9V, 10A).

In the typical form and late form nine to at least 15 proximal thecae (after th1) are rastritiform to subrastritiform, with significant interspaces between the normally straight metathecal tubes. In some specimens in the highest sample (HT120-130), however, the number of rastritiform to sub-rastritiform proximal thecae decreases to less than nine. Distal thecae in the typical form and late form are high-triangulate.

In the proximal to mesial thecae, the prothecae are slender, isolated tubes, $0.07-0.13 \mathrm{~mm}$ wide at th2, $0.1-0.23 \mathrm{~mm}$ at th $5,0.15-0.35 \mathrm{~mm}$ at th 10 and $0.25-0.5 \mathrm{~mm}$ in distal thecae. Prothecal width usually increases towards the metatheca inflection point. On average, prothecal tube widths tend to be in the relatively narrower ends of this range of values in the early form and in the wider end of the range in the late form. Prothecal tubes in the early form and typical form are $0.3-0.8 \mathrm{~mm}$ long at th $3(\mathrm{M}=0.52 \mathrm{~mm}$, $\mathrm{n}=28), 0.3-0.75 \mathrm{~mm}$ at th5 $(\mathrm{M}=0.49 \mathrm{~mm}, \mathrm{n}=35)$ at th5 and $0.25-0.55 \mathrm{~mm}$ at th $10(\mathrm{M}=0.41 \mathrm{~mm}, \mathrm{n}=24)$. Specimens of the late form are marked by more dense thecal spacing (see Tab. 1) and consequently lower prothecal tube length: $0.3-0.7 \mathrm{~mm}$ at th $3(\mathrm{M}=0.45 \mathrm{~mm}, \mathrm{n}=47), 0.15-0.5 \mathrm{~mm}$ at th5 $(\mathrm{M}=0.34 \mathrm{~mm}, \mathrm{n}=52)$, and $0.21 \mathrm{~mm}(\mathrm{n}=44)$ at th10.

The metathecal tubes are generally straight, although they are sometimes ventrally curved in the early form. They widen from $0.12-0.25 \mathrm{~mm}$ at the mid-point of th2 $(\mathrm{M}=0.18 \mathrm{~mm}, \mathrm{n}=31)$, to $0.2-0.35 \mathrm{~mm}$ at th5 $(\mathrm{M}=0.26 \mathrm{~mm}$, $\mathrm{n}=81), 0.35-0.5 \mathrm{~mm}$ at th $10(\mathrm{M}=0.42 \mathrm{~mm}, \mathrm{n}=68)$, and $0.45-0.6 \mathrm{~mm}$ in distal thecae. Specimens of the late form exhibit slightly wider $(0.5-0.65 \mathrm{~mm})$ metathecal tubes in the distal part of mature rhabdosomes. The metathecae are terminated by proximally facing apertures that are transversely extended into a pair of lateral processes. These lateral processes, particularly prominent in specimens of the late form, are $0.1-0.3 \mathrm{~mm}$ long in proximal thecae and commonly up to $0.4 \mathrm{~mm}$ long in mesial and distal thecae (Fig. 9B, D, E, P).

The angle of inclination of the metathecal tubes increases from $57^{\circ}$ at th $2(\mathrm{n}=29)$ in the early and typical

Figure 9. Demirastrites triangulatus (Harkness); A - PŠ 4192, sample HT120-130; B - PŠ 4231, sample HT130-140; C - PŠ 4042, sample HT140-150; D - PŠ 4233, sample HT130-140; E - PŠ 4039, sample HT140-150; F - PŠ 4107, sample HT120-130; G - PŠ 4237/2, sample HT130-140; H PŠ 4271, sample HT170-180; I - PŠ 4248, sample HT185-190; J - PŠ 4268, sample HT180-185; K - PŠ 4043, sample HT140-150; L - PŠ 3990, sample HT160-170; M - PŠ 4249, sample HT185-190; N - PŠ 4214, sample HT150-160; O - SM. A24849, horizon S by Sudbury (1958); P - PŠ 4058, sample HT200-205; Q - PŠ 4269, sample HT195-200; R - MGM9201-O, sample EP440-460; S - PŠ 4246, sample HT180-185; T - PŠ 4301; U - PŠ 4276, sample HT195-200; V - PŠ 4224, sample HT200-205; W - PŠ 3927, sample HT205-207; X - PŠ 4228, sample HT190-195. All specimens from Hlásná Třebaň except for $\mathrm{O}$ from the Rheidol Gorge section, Wales; R from the El Pintado reservoir section, Spain and T from Všeradice. Figures A-H, $\mathrm{K}$, L, and $\mathrm{N}$ represent the late morphotype of the species; figures $\mathrm{M}, \mathrm{I}, \mathrm{J}$ and $\mathrm{R}-\mathrm{T}$ belong to the typical morphotype and figures $\mathrm{O}-\mathrm{Q}$ and $\mathrm{U}-\mathrm{X}$ represent the early morphotype. All figures $\times 6$, scale bar represents $1 \mathrm{~mm}$, crossed bars in figures $\mathrm{O}$ and $\mathrm{R}$ indicate tectonic strain. 


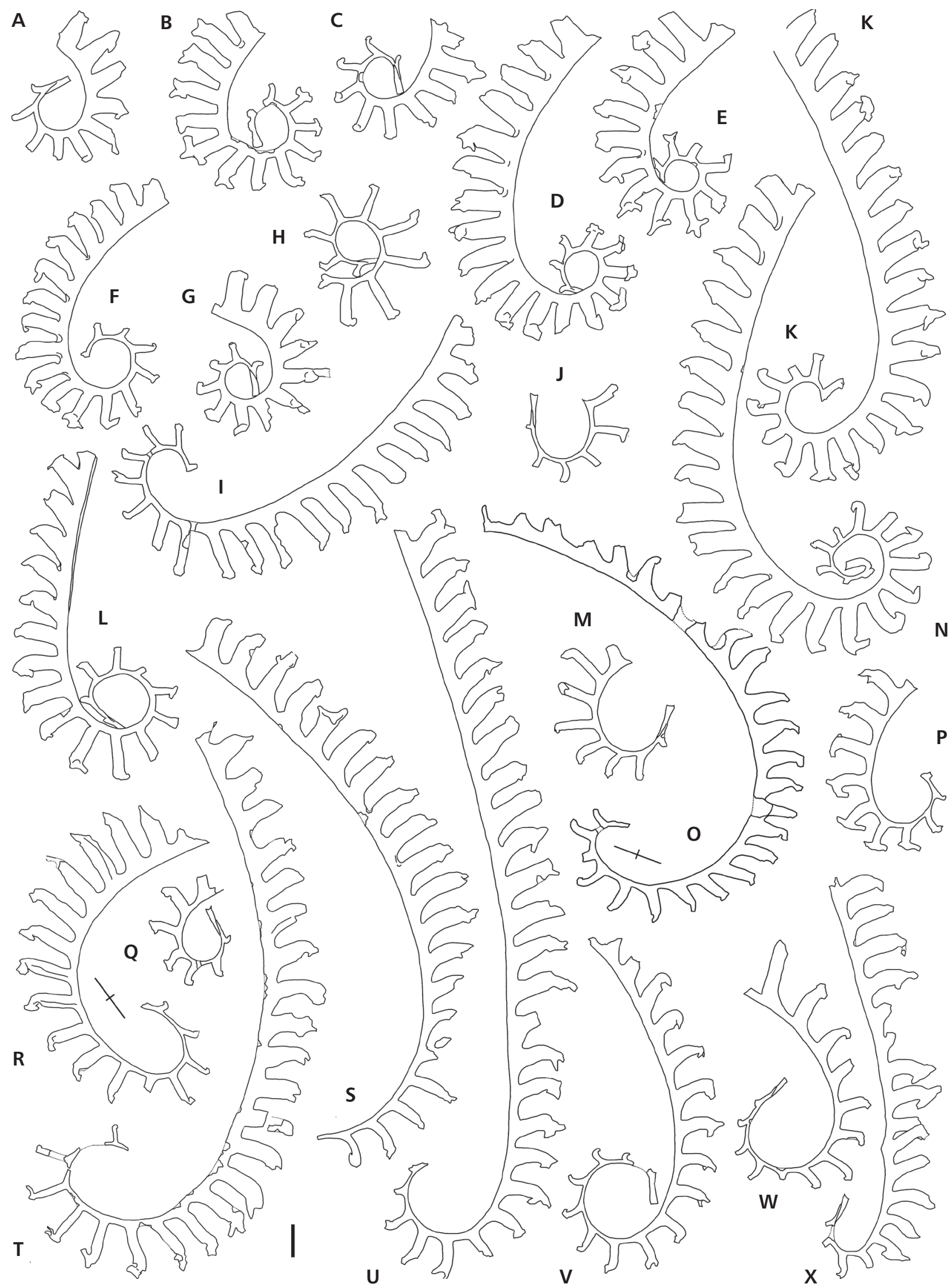


forms, through $79^{\circ}(\mathrm{n}=33)$ at th5, reaching the maximum of $81^{\circ}$ at about th10 $(n=26)$ and decreases again to $73^{\circ}$ $(n=15)$ in distal thecae. Specimens of the late form exhibit slightly, but consistently higher angles of metathecal inclination: $\mathrm{M}=70^{\circ}(\mathrm{n}=35)$ at th2, $\mathrm{M}=83^{\circ}(\mathrm{n}=49)$ at th5, $\mathrm{M}=84^{\circ}(\mathrm{n}=43)$ at th10 and $77^{\circ}$ in the distal part of the rhabdosome.

Discussion. - Monograptus triangulatus separatus, described by Sudbury (1958, as Monograptus separatus separatus, but renamed as M. triangulatus separatus by Sudbury, 1959), based on specimens preserved as internal pyrite moulds from the Rheidol Gorge, was distinguished from Monograptus triangulatus triangulatus by having a slightly lower number of widely separated, rastritiform to sub-rastrititform proximal metathecae and a more gradual increase in DVW. Sudbury found that specimens assigned to Monograptus triangulatus separatus and Monograptus triangulatus triangulatus occurred together in many of the samples in the Rheidol Gorge succession, which suggests that they are not likely to represent either geographical or chronological subspecies of the same species. We have observed that the increase in DVW of the proximal part of the rhabdosome varies considerably in D. triangulatus. Specimens with DVW values similar to Sudbury's definition of M. triangulatus separatus occur in the lowermost triangulatus Biozone in the Prague Synform (D. triangulatus early form). M. triangulatus separatus was reported from a broad interval beginning at the base of the triangulatus Biozone up to the magnus Biozone in the Rheidol Gorge. A specimen that Sudbury had identified as $M$. triangulatus separatus from the base of the triangulatus Biozone is illustrated here (Fig. 90), showing its close similarity to our $D$. triangulatus early form. However, the type specimen of M. triangulatus separatus came from Sudbury's horizon D, which we correlate with lower pectinatus Biozone of continental Europe due to its co-occurrence with $D$. pectinatus $(=$ M. triangulatus fimbriatus $)$ and other age-diagnostic taxa. Several of our stratigraphically higher specimens of $D$. triangulatus (late form) also show a reduced number of rastritiform to sub-rastritiform thecae (e.g. Fig. 9A, G), indicating that this character is also quite variable within this species. In addition, specimens of D. pectinatus with a small number of sub-rastritiform thecae occur in the lowest part of the pectinatus Biozone in the Hlásná Třebaň section. It is difficult to compare precisely the number of rastritiform to sub-rastritiform thecae in flattened specimens with those in three dimensional pyrite internal moulds from the Rheidol Gorge due to variation in the mode of flattening, combined with apparent primary morphological variability. We conclude, therefore, that Demirastrites triangulatus separatus falls well within the variability observed in populations of $D$. triangulatus and we see no basis for distinguishing the "separatus" form as a distinct subspecies.

Demirastrites extremus (Elles \&Wood) can be easily distinguished from Demirastrites triangulatus by having approximately 12 widely spaced rastritiform thecae and a maximum DVW of $2.0-2.5 \mathrm{~mm}$, which is attained between th 9 and th 12 before it gradually decreases to $1.8-2.0 \mathrm{~mm}$ in the distal part of the rhabdosome. As a result, we feel that it is sufficiently distinct from $D$. triangulatus to be regarded as a distinct species, rather than as a subspecies of the latter.

Based on the figured specimens (pl. 20, figs 64-66) and diagnosis provided by Sudbury (1958), Demirastrites predecipiens can be distinguished by its more axially elongated proximal thecae and lesser $(1.2-1.4 \mathrm{~mm})$ and more gradually increasing DVW. The widely separated proximal thecae, reported as rastritiform by Sudbury, appear sub-rastritiform on the figured specimens. The true status of this form will have to be re-examined based on its type collection supplemented by additional material.

Monograptus triangulatus var. Raitzhainiensis was recognized by Eisel (1899) and later described by Törnquist (1907) and Eisel (1908), based on flattened material that was heavily deformed by tectonic strain, which created the appearance of its short and broad, beak-like distal thecae. The validity of this form was questioned by Törnquist (1907), and the lectotype, designated by Přibyl \& Münch (1942), is missing. Based on the published illustrations and descriptions we consider that the original material on which this species is based most likely represents tectonically deformed specimens of $D$. triangulatus.

Demirastrites triangulatus has been considered to be one of the most cosmopolitan species of the Llandovery graptolite fauna. However, we have closely examined specimens assigned to $D$. triangulatus in China and Siberia and have found significant differences from the material assigned to this species in Europe. The maximum distal width of Chinese and Russian specimens is only $1.5 \mathrm{~mm}$ with mean DVW values of $1.2-1.3 \mathrm{~mm}$. Their metathecae are more triangular (less parallel-sided), and more widely spaced in the proximal part, separated by wider interspaces throughout the rhabdosome. The apertural hooks are more rounded and lateral apertural processes appear to be shorter. The prothecae commonly widen more toward the base of the metatheca. The dorsal curvature of the rhabdosome is less accentuated proximally in the Chinese and Siberian specimens and the proximal end possesses a slightly ventrally curved, rather than straight, sicula. The Chinese and Russian material may represent a different, although closely related species, although, conversely, they could represent a geographical subspecies of $D$. triangulatus. For this reason, we regard the synonymy of the Chinese and Russian material with $D$. triangulatus as questionable, pending detailed comparative morphometric study. 

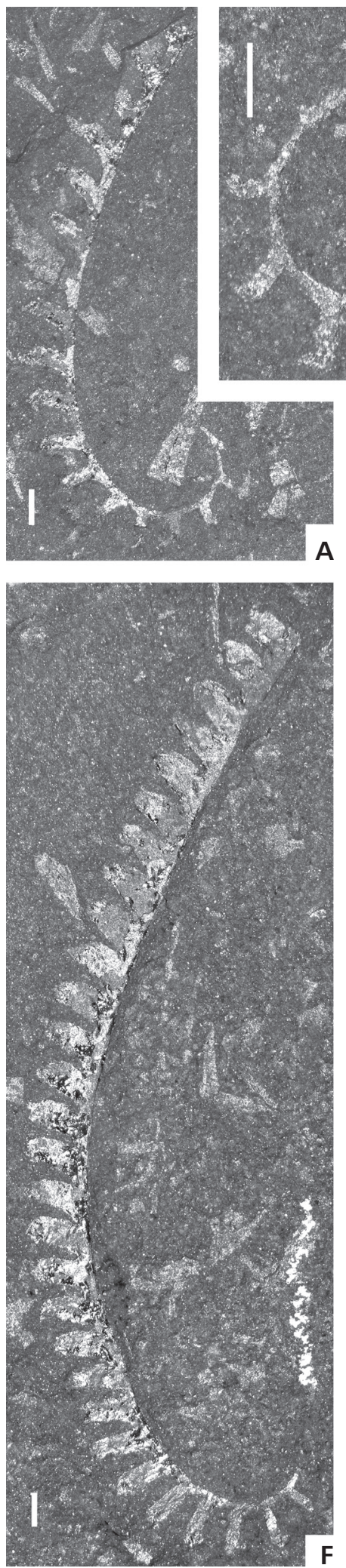

A
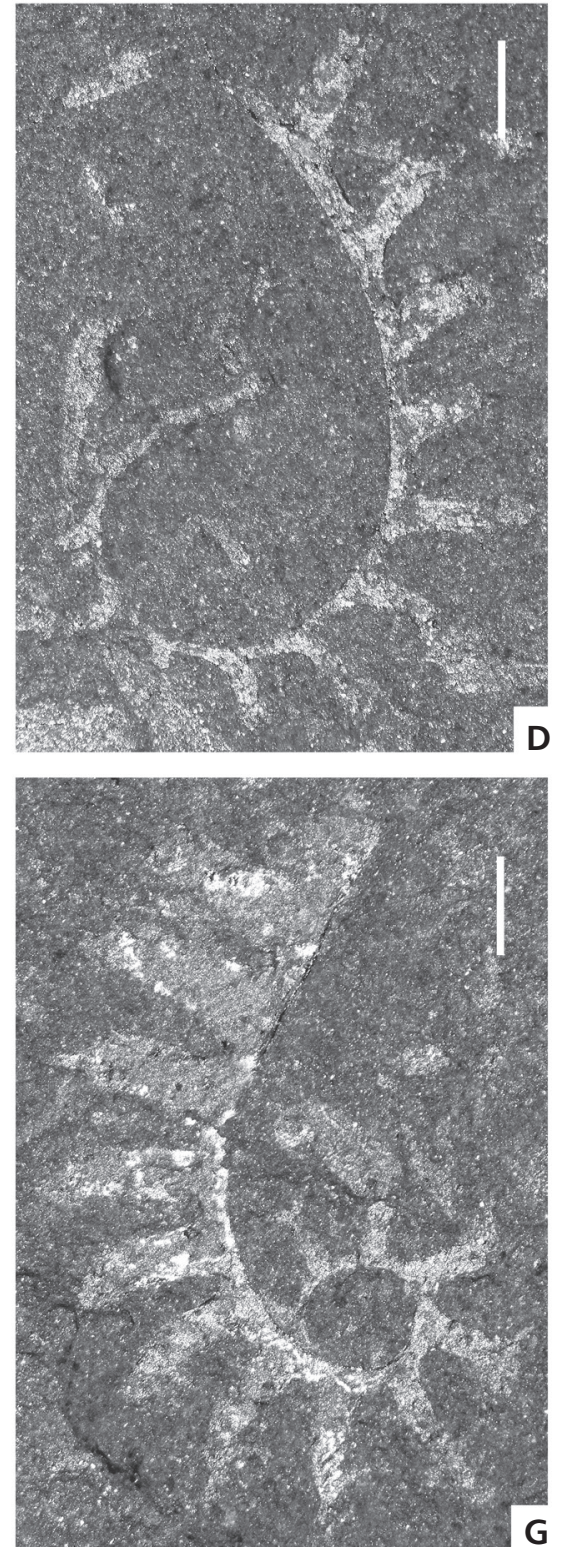

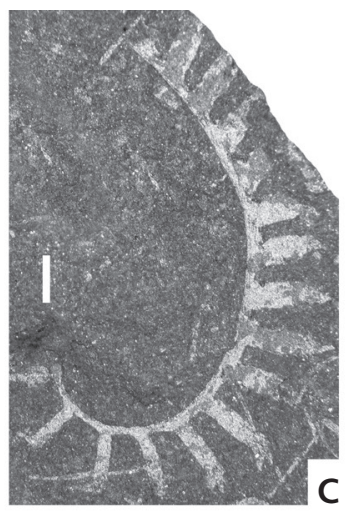

C

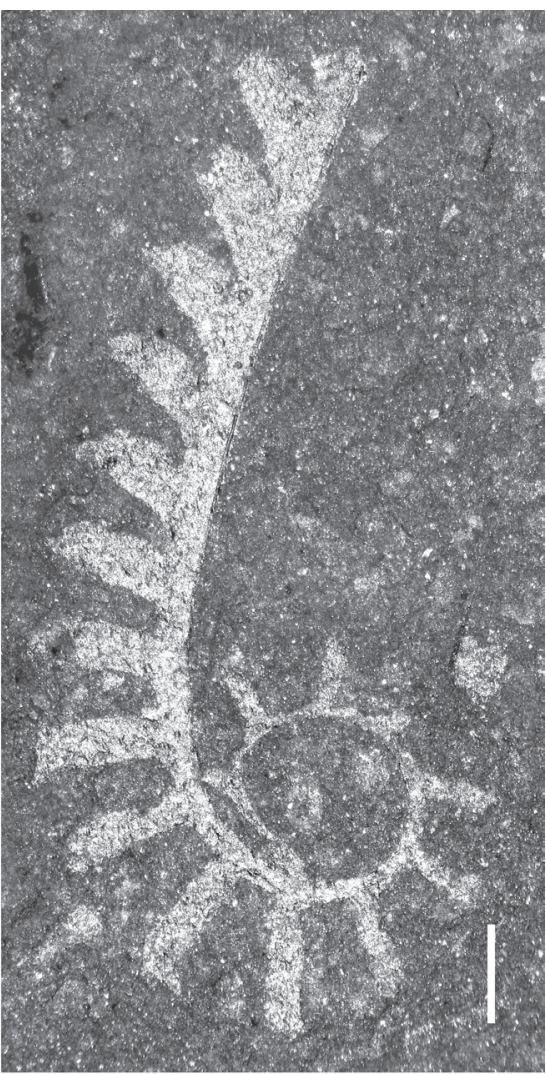

$\mathbf{E}$

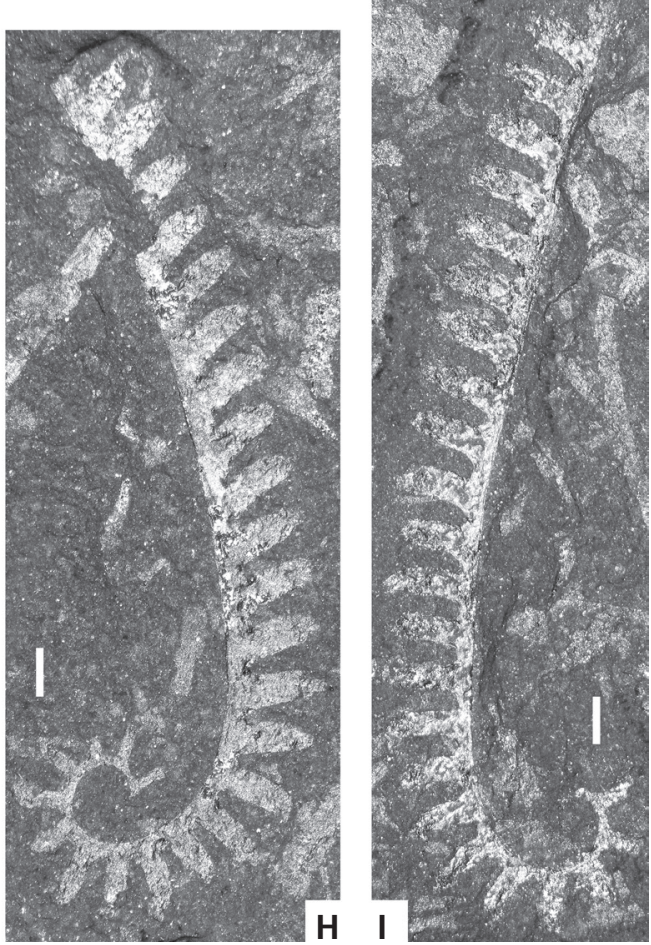

Figure 10. Demirastrites triangulatus (Harkness). A A, D - early morphotype of the species; A - PŠ 4310, sample HT205 - 207; D - PŠ 4304, sample HT205-207. • B, C, F, I - typical morphotype; B - PŠ 4267, sample HT185-190; C - PŠ 4216, sample HT195-200; F - PŠ 4210, sample HT180-185; I - PŠ 4244, sample HT190-195. • E, G, H - late morphotype; E - PŠ 3990, sample HT160-170; G - PŠ 4039, sample HT140-150; H - PŠ 4043, sample HT140-150. All specimens from Hlásná Třeban̆. Figures A, C, F, H-I, ×5; figures B, D, E, G, ×10; scale bars represent $1 \mathrm{~mm}$. 


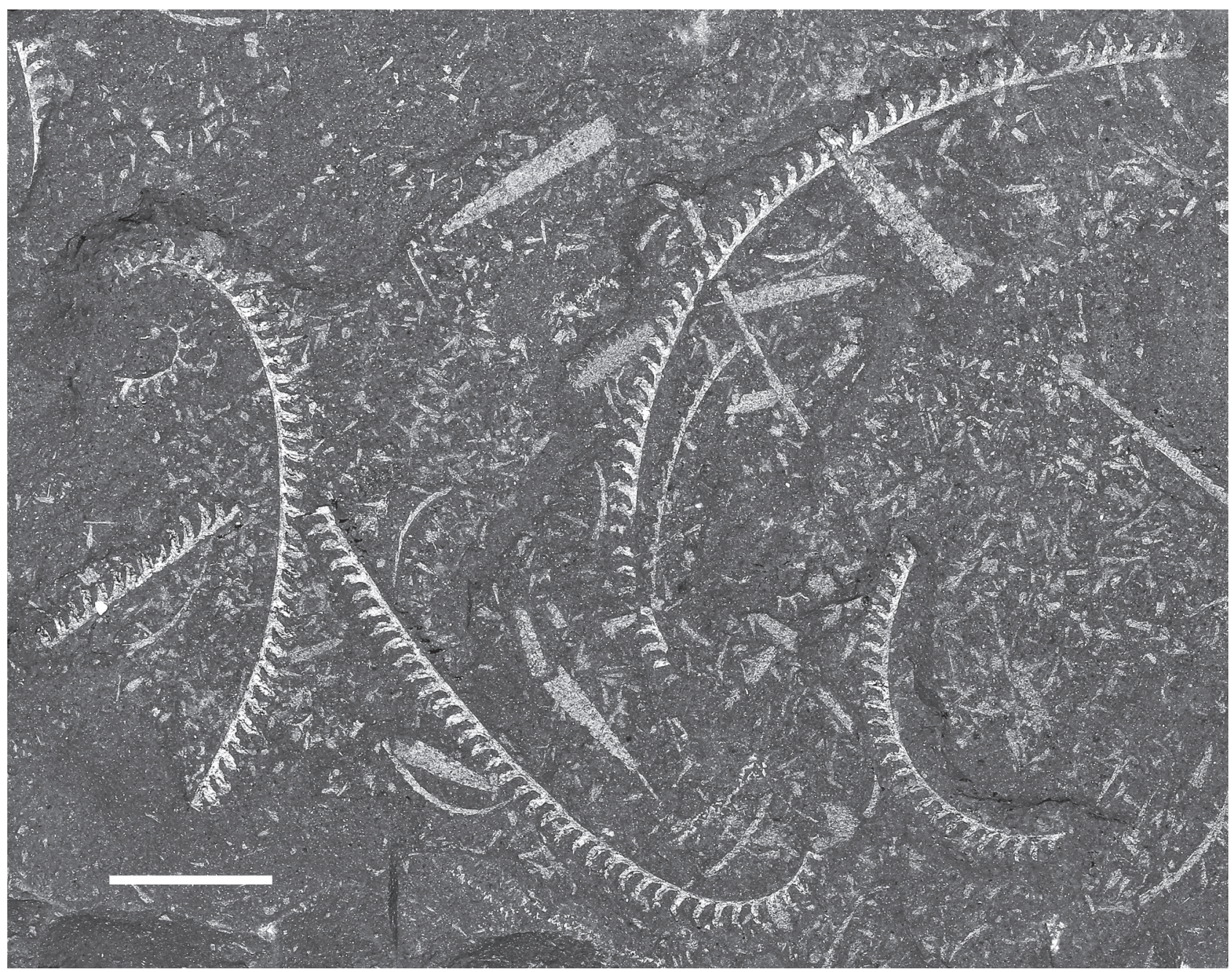

Figure 11. Demirastrites triangulatus (Harkness), early morphotype of the species; PŠ 4281, Hlásná Třebaň, sample HT190-195. Scale bar represents $10 \mathrm{~mm}$.

\section{Morphological changes, anagenesis, and speciation}

Large collections of specimens of Demirastrites derived from bed-by-bed sampling of the lower Aeronian succession in the Prague Synform, supplemented by specimens from other localities in peri-Gondwanan Europe, have made it possible to document both gradual morphological changes within species and also patterns of apparent species divergence, which are shown in Fig. 2.

As noted above, populations of Demirastrites triangulatus can be divided into three distinct morphotypes. The early form (Figs 9O-Q, U-X; 10A, D; 11) is confined to the lowermost $22 \mathrm{~cm}$ of the species' range at Hlásná Třebaň (Fig. 2). It is common in four samples (HT200-207, HT195-200, HT190-195 and HT185-190). Within the relatively short range of the early form there appears to be a distinct trend toward increasing distal DVW and also greater mesial and distal metathecal width in higher collections (Fig. 12B, C). A second, slightly different morphotype (Figs 9M, I, J, R-T; 10B, C, F, I) co-occurs with the early form in samples HT195-200 and 185-190, and also occurs in the overlying sample, HT180-185. Despite its relatively short range at Hlásná Třebaň, we refer to this as the typical form because it most closely resembles specimens identified as this species in other studies of European material. Although there is significant overlap in the morphologies of the early form and the typical form, the early form differs from the typical form in the following respects: the DVW increases more slowly in the early form, which is particularly evident in its lower mean DVW at th10 (Tab. 1); the metathecae are commonly slightly ventrally curved in the early form, which is rare in the typical form (Fig. 9); distal 2TRD is generally higher in the early form (Tab. 1); the early form commonly retains sub-rastritiform thecae throughout the length of the rhabdosome, which is rare in the typical form; the typical form commonly shows several fully rastritiform thecae 
in the proximal end, which are not seen in the early form. There are no evident morphological changes within the typical form through its range.

The third morphotype of $D$. triangulatus is the late form (Figs 9A-H, K, L, N; 10E, G, H), which occurs in all samples from HT170-180 (the sample above the highest occurrence of the typical form) to HT120-130, in the lower part of the pectinatus Biozone (Fig. 2). Its most conspicuous difference from the early and typical forms is that the late form shows a significantly more tightly coiled rhabdosome through the first ten thecae. The late form also differs from the typical form in that it possesses, on average, more closely spaced and less inclined thecae, as well as commonly showing more strongly developed lateral processes. As in the typical form, several of the proximal thecae are fully rastritiform in the late form. The late form of $D$. triangulatus shows a clear pattern of gradual morphological change in its proximal thecal spacing, with the 2TRD decreasing through its range (Fig. 12A). In addition, the stratigraphically highest specimens tend to have a lower number of rastritiform to sub-rastritiform thecae.

Two distinct forms are recognizable among specimens of Demirastrites pectinatus (Fig. 2). The early form (Figs $6 \mathrm{~F} ; 8 \mathrm{~J}, \mathrm{M}, \mathrm{Q}-\mathrm{R}$ ) is restricted in its stratigraphical range to the HT130-140, HT120-130 and HT110-120 samples and overlaps in the lower two samples with late form of $D$. triangulatus. The early form of $D$. pectinatus closely resembles the late form of $D$. triangulatus in several respects, particularly in that they retain 4-5 subrastritiform thecae in the proximal end. On the other hand, the early form of $D$. pectinatus differs from the late form of D. triangulatus in the following respects (Fig. 2): loss of fully rastritiform proximal thecae and fewer sub-rastritiform proximal thecae; a more weakly coiled proximal part of the rhabdosome; less pronounced lateral apertural processes; lower 2TRD values, particularly proximally and mesially (Tab. 1); and increased metathecal width (Fig. 12C). Further changes from the early form to the late form of

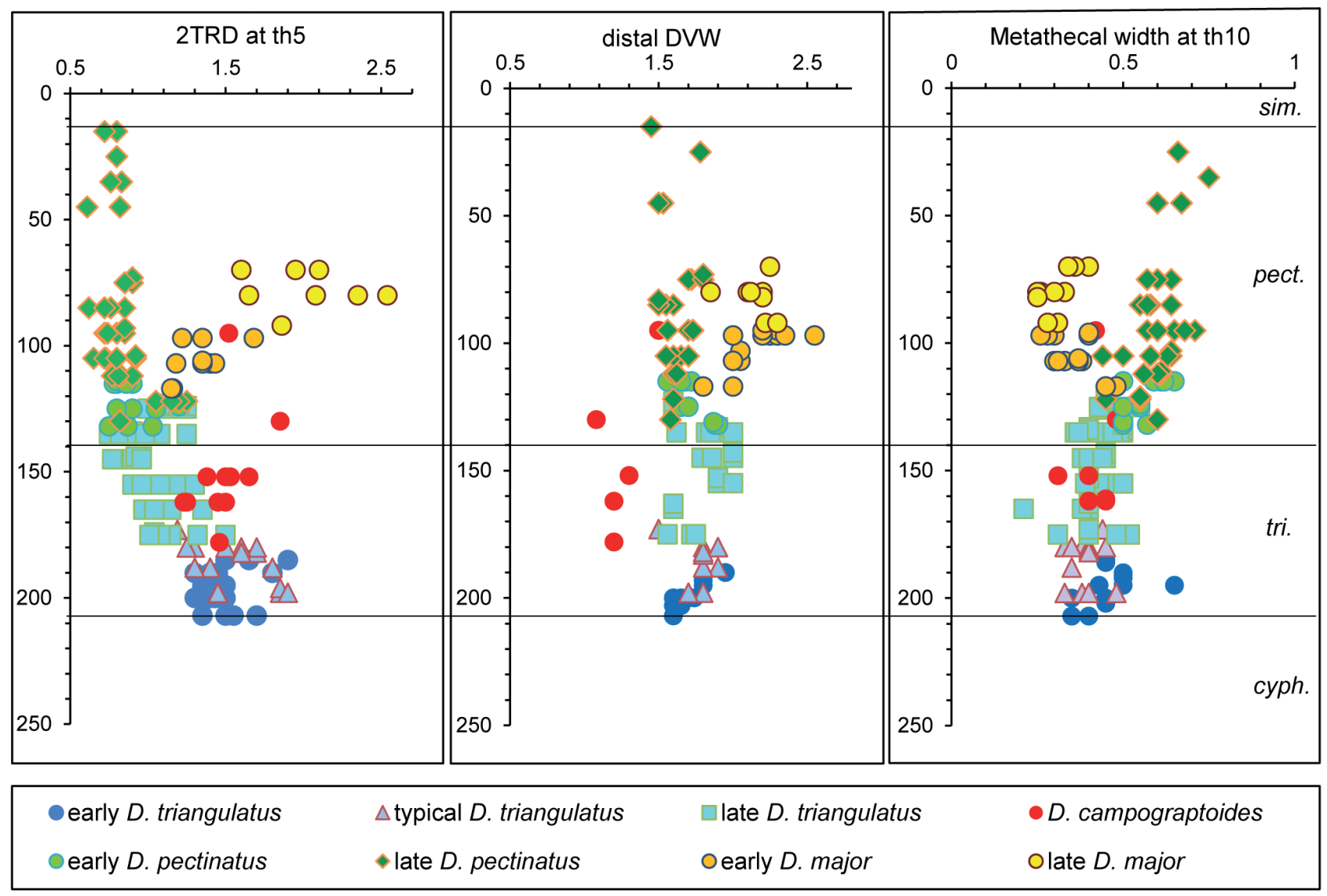

Figure 12. Some morphological trends observed in demirastritids of the triangulatus group in the Hlásná Třeban̆ section shown by plots of selected morphometric data versus stratigraphical level (vertical axis). $・$ A - comparison of species and morphotypes using proximal thecal spacing (2TRD at th 5) of the specimen plotted against its stratigraphical level. $\bullet \mathrm{B}$ - distal dorso-ventral width (DVW distal) versus stratigraphical level. $\bullet \mathrm{C}-$ comparison of species and morphotypes through metathecal width of th10 versus stratigraphical level. Vertical scale refers to samples HT (205-207)-HT (0-20) listed on the left side of the section log in Fig. 2. Abbreviations: cyph. - cyphus Biozone; tri. - triangulatus Biozone; pect. - pectinatus Biozone; sim. simulans Biozone. 
D. pectinatus include further decrease in the curvature of the proximal part, lessening of the mesial to distal rhabdosome width (Fig. 12B and also Fig. 6F versus 6I) due to lower thecal inclination; further reduction in the number of sub-rastritiform proximal thecae; and further widening of the metathecae, particularly in the stratigraphically highest collections (Figs 8C, 12C). The widening of the metathecae in the late form of $D$. pectinatus is unlikely to be caused solely by more intense flattening of the rhabdosome because associated specimens Demirastrites major in the pectinatus Biozone possess rather slender thecae throughout.

As with D. pectinatus, there are two distinct forms of Demirastrites major, an early form and a late form. The early form (Figs 6E; 7D, E, H-L) occurs in the HT110-120, HT100-110 and HT90-100 samples, first appearing in the sample immediately above the highest occurrence of D. triangulatus (Fig. 2). The stratigraphically lowest specimens of $D$. major closely resemble the late form of D. triangulatus, including the possession of relatively a tightly coiled proximal part of the rhabdosome, but differ primarily in that specimens of early $D$. major commonly possess a larger number of parallel-sided proximal to mesial thecae, metathecae that are commonly slightly ventrally curved throughout, more pronounced lateral apertural processes, and more closely spaced distal thecae. There are clear morphological trends within the short range of the early form of D. major that further distinguish it from $D$. triangulatus, which also appear to change gradationally from the early to the late form of D. major (Figs 6B, C, J; $7 \mathrm{~A}-\mathrm{C}, \mathrm{F})$, which occurs in the HT90-100, 80-90 and 70-80 samples: increasing proximal 2TRD (Fig. 12A); increasing distal DVW (Fig. 12B); decreasing metathecal width mesially and distally (Fig. 12C); an increasing number of parallel-sided (but ventrally curved) proximal to mesial metathecae (Fig. 7); and a more gradual increase in DVW throughout the length of the rhabdosome (Tab. 1).

Demirastrites campograptoides, with its robust, relatively low and inclined distal thecae with rounded apertural hooks and short lateral processes, seems to be quite morphologically distinct from the other species of Demirastrites in this study. The limited data suggest that it may show an increase in its proximal 2TRD throughout at least part of its range but more data are required to support this apparent trend.

Although the morphological patterns described above have been documented only in a single stratigraphical succession, these observations lead us to propose that some of the apparent trends may represent anagenetic or cladogenetic events within the lineages. For example, the very strong similarities in many characters between the highest specimens of the late form of $D$. triangulatus and the early form of $D$. pectinatus suggest that the divergence of these lineages represents a speciation event that took place at the level recognized as the base of the pectinatus
Biozone (Fig. 2, event 2). Whereas some characters change gradually through this event (e.g. mesial-distal metathecal width and reduction in number of proximal sub-rastritiform thecae), others (e.g. reduction in degree of proximal coiling) change abruptly. The same can be said of the apparent transition from late $D$. triangulatus to early D. major (Fig. 2, event 3), which involves some gradual (e.g. increasing proximal 2TRD, distal DVW, and increasing number of parallel-sided thecae) and some more abrupt (e.g. ventrally curved metatheca with more pronounced lateral apertural processes) changes marking the speciation event. In addition, several of the forms show more gradual changes within their individual ranges, which could be interpreted as anagenetic changes. Examples include: changes within the range of $D$. triangulatus (Fig. 2, event 4), including gradually decreasing proximal $2 \mathrm{TRD}$, particularly within the range of the late form; gradually increasing proximal 2TRD within the range of D. major (Fig. 2, event 7); gradually increasing metathecal width, and further decreases in the number of sub-rastritiform proximal thecae within the range of $D$. pectinatus (Fig. 2, event 6). Limited material does not allow for any further insights into the evolutionary origin or anagenetic trends in D. campograptoides at this time.

It is important to reiterate that these trends have only been fully documented in a single section and must be tested in other sections that show a similarly complete record through this interval. The proposed anagenetic trends, in particular, could be the result of local ecophenotypic variation through the study section, rather than evolutionary trends within the species as a whole. In addition, the proposed phylogenetic relationships could be tested using cladistic analysis of species of Demirastrites together with other taxa that are likely to be closely related.

\section{Conclusions}

1) Lower Aeronian "triangulate monograptids" assigned to to the genus Demirastrites Eisel, 1912 are represented by D. triangulatus (Harkness), D. major (Elles \& Wood), D. pectinatus (Richter) and D. campograptoides sp. nov. in the Prague Synform of the Barrandian area, Czech Republic. Demirastrites extremus (Sudbury, 1958) and Demirastrites predecipiens (Sudbury, 1958) have not been identified here and have been previously found only in Britain. Also ?Demirastrites similis (Elles \& Wood, 1913) had been recorded solely from Britain until its recent discovery in Myanmar by Loydell \& Aung (2017). Demirastrites triangulatus separatus (Sudbury 1958) is not considered here to be a distinct subspecies, and Demirastrites raitzhainiensis (Eisel, 1912) is regarded here to be a junior synonym of $D$. triangulatus. Specimens that are potentially assignable to Demirastrites triangulatus separatus and $D$. 
triangulatus triangulatus exhibit morphological features and dimensions that fall within what we have observed to be a continuous range of variation of a single taxon, accounting for differences in mode of preservation of the type material and our collections. Differences between Demirastrites raitzhainiensis and D. triangulatus can be accounted for by the fact that the former has been strongly deformed by tectonic strain. In addition, Demirastrites triangulatus fimbriatus (Nicholson, 1868), which corresponds with D. pectinatus in all relevant morphological characters, dimensions and stratigraphical occurrence, is considered a junior synonym of the latter taxon.

2) Although our morphological data are derived mainly from only one section, they suggest the possibility that $D$. triangulatus underwent significant anagenetic changes throughout its range. This lineage then split at about the level of sample HT130-140 and gave rise to D. pectinatus, which marks the base of the pectinatus Biozone, which then underwent further anagenetic changes between its early and late forms. At a slightly later stage the $D$. triangulatus lineage underwent significant changes, giving rise, at the level of sample HT90-100, to D. major, which then saw further significant anagenetic changes before it became extinct in the middle pectinatus Biozone (Fig. 2). It is, however, possible that some of the changes interpreted here to be anagenetic evolutionary trends could be local ecophenotypic changes within the broader ranges of the taxa. Further comparative morphometric work and phylogenetic analysis using material from other regions will be required to test these hypotheses. Demirastrites campograptoides is a new species, to date recognized solely in collections from Hlásná Třebaň and Všeradice.

\section{Acknowledgements}

Petr Štorch greatly appreciates the financial support provided by the Czech Science Foundation through project 14-16124S, in-house support received from the Institute of Geology of the Academy of Sciences of the Czech Republic (RVO 67985831), and support provided by St. Francis Xavier University, Antigonish, Nova Scotia, through the James Chair Visiting Professorship during the 2018-2019 academic year. Michael J. Melchin acknowledges the financial support of a Natural Sciences and Engineering Research Council (Canada) Discovery Grant, as well as logistical support for fieldwork in the Arctic from the Polar Continental Shelf Project. We thank J. Fan and Q. Chen for supporting and facilitating our work in China, including access to Chinese graptolite collections and our joint study of Chinese sections, and also A. Lenz for providing some of his Yukon collections to MJM. We are indebted to V. Turek and L. Váchová who photographed the shale slab in Fig. 11 and Š. Manda and J. Kotek who assisted in the field. Finally, we thank D. K. Loydell and V. Sachanski for their helpful reviews of the manuscript.

\section{References}

Anhui Geological Survey 1982. Graptolites of Anhui Province. 166 pp. Anhui Science and Technology Publishing House, Hefei. [in Chinese]

BJERRESKov, M. 1975. Llandoverian and Wenlockian graptolites from Bornholm. Fossils and Strata 8, 1-94.

BOUČEK, B. 1953. Biostratigraphy, development and correlation of the Želkovice and Motol Beds of the Silurian of Bohemia. Sbornik Ústředního Ústavu geologického, Oddil paleontologický 20, 421-484.

Bulman, O.M.B. 1957. Proposed use of the plenary powers to designate for three taxa belonging to the Class Graptolithina lectotypes which will secure the continued use of the names concerned in their accustomed sense. Bulletin of Zoological Nomenclature 13, 313-317. DOI 10.5962/bhl.part.3567

Challinor, J. 1945. A graptolite lineage from North Cardiganshire. Geological Magazine 82, 97-106. DOI 10.1017/S0016756800078055

Chen, X. 1984. Silurian graptolites from southern Shaanxi and northern Sichuan with special reference to classification of Monograptidae. Palaeontologia Sinica, New Series B 20, 1-102. [in Chinese, with English summary]

Chen, X. \& Lin, Y.-K. 1978. Lower Silurian graptolites from Tongzi, northern Guizhou. Memoir of the Nanjing Institute of Geology and Palaeontology, Academia Sinica 12, 1-106. [in Chinese, with English abstract]

Cooper, R.A. \& Lindholm, K. 1990. A precise worldwide correlation of early Ordovician graptolite sequences. Geological Magazine 127, 497-525. DOI 10.1017/S0016756800015429

Cooper, R.A., SAdler, P.M., Munnecke, A. \& Crampton, J.S. 2014. Graptoloid evolutionary rates track Ordovician-Silurian global climate change. Geological Magazine 151, 349-364. DOI 10.1017/S0016756813000198

Cullum, A.A. \& Loydell, D.K. 2011. The Rhuddanian/Aeronian transition in the Rheidol Gorge, mid Wales. Proceedings of the Yorkshire Geological Society 58(4), 261-266. DOI 10.1144/pygs.58.4.299

Dawson, D.H. 2007. Phylogenetic study of the earliest Silurian Monograptus (Graptolithina) and related taxa, Cape Phillips Formation, Nunavut, Canada. 176 pp. Master thesis. St. Francis Xavier University, Antigonish.

EISEL, R. 1899. Über die Zonenfolge Ostthüringischer und Vogtländischer Graptolithenschiefer. Jahresberichte der Gesellschaft von Freunde der Naturwissenschaften in Gera 39/42, 49-62.

EISEL, R. 1908. Über Verdrückungen thüringisch-sächsischer Graptolithenformen. Zeitschrift für Naturwissenschaften. Organ des naturwissenschaftlichen Vereins für Sachsen und Thüringen, Halle AS 80, 218-221.

EISEL, R. 1912. Über zonenweise Entwicklung der Rastriten und Demirastriten. Jahresberichte der Gesellschaft von Freunde der Naturwissenschaften in Gera 53/54, 27-43.

Elles, G.L. \& Wood, E.M.R. 1913. A monograph of British graptolites. Part 9. Monograph of the Palaeontographical Society 66(323), 415-486.

DOI 10.1080/02693445.1913.12035561 
Fan, J.-X., Chen, Q., Melchin, M.J., Sheets, H.D., Chen, Z.-Y., Zhang, L.-N. \& Hou, X.-D. 2013. Quantitative stratigraphy of the Wufeng and Lungmachi black shales and graptolite evolution during and after the Late Ordovician mass extinction. Palaeogeography, Palaeoclimatology, Palaeoecology 389, 96-114. DOI 10.1016/j.palaeo.2013.08.005

Harkness, R. 1851. Description of the graptolites found in the black shales of Dumfriesshire. Quarterly Journal of the Geological Society of London 7, 58-65.

DOI 10.1144/GSL.JGS.1851.007.01-02.16

Howe, M.P.A. 1983. Measurement of thecal spacing in graptolites. Geological Magazine 120, 635-638. DOI 10.1017/S0016756800027795

HutT, J. E. 1975. The Llandovery graptolites of the English Lake District. Part 2. Monograph of the Palaeontographical Society 129(542), 57-137.

JAEGER, H. \& SCHÖNLAUB, H.P. 1977. Das Ordoviz/Silur-Profil im Nölblinggraben (Karnische Alpen, Österreich). Verhandlungen der Geologischen Bundesanstalt 1977, 349-359.

Jones, H., Zalasiewicz, J. \& Rickards, R.B. 2002. Clingfilm preservation of spiraliform graptolites: Evidence of organically sealed Silurian seafloors. Geology 30, 343-346.

DOI 10.1130/0091-7613(2002)030<0343:CPOSGE $>2.0 . C O ; 2$

JoNES, O.T. 1909. The Hartfell-Valentian succession in the district around Plynlimon and Pont Erwyd (North Cardiganshire). Quarterly Journal of the Geological Society of London 65, 463-537. DOI 10.1144/GSL.JGS.1909.065.01-04.32

LAPWORTH, C. 1873. On an improved classification of the Rhabdophora. Geological Magazine 10(1), 500-504, 555-560. DOI 10.1017/S0016756800469256

Lenz, A.C. 1982. Llandoverian graptolites of the Northern Canadian Cordillera: Petalograptus, Cephalograptus, Rhaphidograptus, Dimorphograptus, Retiolitidae, and Monograptidae. Life Sciences Contributions Royal Ontario Museum 130, 1-154. DOI 10.5962/bhl.title.60100

LI, J.-J. 1995. Lower Silurian graptolites from the Yangtze Gorge district. Palaeontologia Cathayana 6, 215-344.

Loydell, D.K. 1993. Upper Aeronian and lower Telychian (Llandovery) graptolites from western mid-Wales. Part 2. Palaeontographical Society Monograph 147(592), 56-180.

Loydell, D.K. 2012. Graptolite biozone correlation charts. Geological Magazine 149, 124-132. DOI $10.1017 / \mathrm{S} 0016756811000513$

Loydell, D.K. \& Aung, K.P. 2017. The "Panghkawkwo graptolite bed" (Llandovery, Silurian), Myanmar and the location of the Sibumasu (or Sibuma) Terrane in the Silurian. Palaeogeography, Palaeoclimatology, Palaeoecology 469, 1-17. DOI 10.1016/j.palaeo.2016.12.028

Loydell, D.K., Frýda, J. \& Gutiérrez-Marco, J.C. 2015. The Aeronian/Telychian (Llandovery, Silurian) boundary, with particular reference to sections around the El Pintado reservoir, Seville province, Spain. Bulletin of Geosciences 90, 743-794. DOI 10.3140/bull.geosci.1564

Loydell, D.K., Männik, P. \& Nestor, V. 2003. Integrated biostratigraphy of the lower Silurian of the Aizpute-41 core, Latvia. Geological Magazine 140, 205-229.

DOI $10.1017 / \mathrm{S} 0016756802007264$
Loydell, D.K., Walasek, N., Schovsbo, N.H. \& Nielsen, A.T. 2017. Graptolite biostratigraphy of the lower Silurian of the Sommerodde-1 core, Bornholm, Denmark. Bulletin of the Geological Society of Denmark (DGF) 65, 135-160.

Melchin, M.J. 1989. Llandovery graptolite biostratigraphy and paleobiogeography, Cape Phillips Formation, Canadian Arctic Islands. Canadian Journal of Earth Sciences 26, 1726-1746. DOI 10.1139/e89-147

Melchin, M.J. \& Holmden, C. 2006. Carbon isotope chemostratigraphy of the Llandovery in Arctic Canada: Implications for global correlation and sea-level change. GFF 128(2), 173-180. DOI 10.1080/11035890601282173

Melchin, M.J., Lenz, A.C. \& KozŁowska, A. 2017. Retiolitine graptolites from the Aeronian and lower Telychian (Llandovery, Silurian) of Arctic Canada. Journal of Paleontology 91, 116-145. DOI 10.1017/jpa.2016.107

Melchin, M.J., Sadler, P.M. \& Cramer, B.D. 2012. The Silurian Period, 525-558. In Gradstein, F.M., OGG, J.G., Smith, A.G. \& OGG, G.M. (eds) The Geologic Time Scale 2012. Elsevier, Amsterdam.

Melchin, M.J., Boom, A., Davies, J.R., De Weirdt, J., McIntyre, A.J., Morgan, G., Phillips, S., Russell, C., Vandenbroucke, T.R.A., Williams, M. \& Zalasiewicz, J.A. 2016b. Integrated stratigraphic study of the Rhuddanian-Aeronian (Llandovery, Silurian) boundary succession at Rheidol Gorge, Wales. Abstracts of IGCP 591 Meeting, Ghent.

Melchin, M.J., Davies, J.R., De Weirdt, J., Russell, C., VanDenbroucke, T.R.A. \& Zalasiewicz, J.A. 2018. Integrated stratigraphic study of the Rhuddanian-Aeronian (Llandovery, Silurian) boundary succession at Rheidol Gorge, Wales: a preliminary report. 16 pp. Open Report OR/18/39, British Geological Survey.

Melchin, M.J., Sheets, H.D., Mitchell, C.E. \& Fan, J. 2016 a. A new approach to quantifying stratigraphical resolution: application to global stratotypes. Lethaia 50, 407-423. DOI 10.1111/let.12193

NI, Y.-N. 1978. Lower Silurian graptolites from Yichang, western Hubei. Acta Palaeontologica Sinica 17, 387-416. [in Chinese]

Nicholson, H.A. 1868. On the graptolites of the Coniston Flags; with notes on the British species of the genus Graptolites. Quarterly Journal of the Geological Society of London 24, 521-545. DOI 10.1144/GSL.JGS.1868.024.01-02.67

Овut, A.M., Sobolevskaya, R.F. \& Bondarev, V.I. 1965. Graptolity silura Taimyra. 120 pp. Akademiya Nauk USSR, Sibirskoje Otdelenie, Institut Geologii i Geofiziki, Moskva. [in Russian]

Obut, A.M., Sobolevskaya, R.F. \& Merkureva, A.P. 1968. Graptolity Llandoveri v Kernakh Burovykh Skvazhin Norilskogo Rayona, 162 pp. Akademiya Nauk USSR, Sibirskoje Otdelenie, Institut Geologii i Geofiziki, Moskva. [in Russian]

Овut, A.M., Sobolevskaya, R.F. \& Nikolaev, A.A. 1967. Graptolity i Stratigrafiya Nizhnego Silura Okrainnykh Podnyatii Kolymskogo Massiva, 164 pp. Akademiya Nauk SSR, Sibirskoje Otdelenie, Institut Geologii i Geofiziki. Ministerstvo Geologii SSSR, Nauchno-Issledovatel'sky Institut Geologii Arktiki, Moskva. [in Russian] 
PAŠKEVIČIUS, J. 1979. Biostratigraphy and Graptolites of the Lithuanian Silurian. 267 pp. Mokslas, Vilnius. [in Russian, with English summary]

Perner, J. 1897. Études sur les Graptolites de Bohême. Part 3. section a. 25 pp. Raimond Gerhard, Prague.

Piçarra, J.M., Robardet, M., Oliveira, J.T., Paris, F. \& Lardeux, H. 2009. Graptolite faunas of the Llandovery "phtanites" at Les Fresnaies (Chalonnes-sur-Loire, southeastern Armorican Massif): Palaeontology and biostratigraphy. Bulletin of Geosciences 84, 41-50. DOI 10.3140/bull.geosci.1085

PřIBYL, A. \& MüNCH, A. 1942. Revize středoevropských zástupců rodu Demirastrites Eisel. Rozpravy České akademie věd a umění, Tř́da 2 51(31), 1-29.

Richter, R. 1853. Thüringische Graptolithen. Zeitschrift der Deutschen geologischen Gesellschaft 5, 439-464.

Rickards, R.B. 1970. The Llandovery (Silurian) graptolites of the Howgill Fells, northern England. Monograph of the Palaeontographical Society 123(524), 1-108.

Rickards, R.B., Hutt, J.E. \& Berry, W.B.N. 1977. Evolution of the Silurian and Devonian graptoloids. Bulletin of the British Museum (Natural History), Geology 28, 1-120.

SADLER, P.M. 2004. Quantitative biostratigraphy: achieving finer resolution in global correlation. Annual Review of Earth and Planetary Sciences 32, 187-213.

DOI 10.1146/annurev.earth.32.101802.120428

SAdler, P.M., Cooper, R.A. \& Melchin, M.J. 2011. Sequencing the graptoloid clade: building a global diversity curve from local range charts, regional composites and global timelines. Proceedings of the Yorkshire Geological Society 58(4), 329-343. DOI 10.1144/pygs.58.4.296

Sadler, P.M., Kemple, W.G. \& Kooser, M.A. 2003. Contents of the compact disk - CONOP9 programs for solving the stratigraphic correlation and seriation problems as constrained optimization, 461-465. In HARRIES, P.J. (ed.) High resolution approaches in stratigraphic paleontology. Kluwer Academic Publishers, Dordrecht.

Schauer, M. 1971. Biostratigraphie und Taxionomie der Graptolithen des tieferen Silurs unter besonderer Berucksichtigung der tektonischen Deformation. Freiberger Forschungshefte, C273 Paläontologie, 1-185.

SHAw, A.B. 1964. Time in stratigraphy. 365 pp. McGraw Hill, New York.

Sheets, H.D., Mitchell, C.E., Izard, Z.T., Willis, J.M., Melchin, M.J. \& Holmden, C. 2012. Horizon annealing a collectionbased approach to automated sequencing of the fossil record. Lethaia 45, 532-547. DOI 10.1111/j.1502-3931.2012.00312.x
ŠTorCH, P. 1994. Graptolite biostratigraphy of the Lower Silurian (Llandovery and Wenlock) of Bohemia. Geological Journal 29, 137-165. DOI 10.1002/gj.3350290204

ŠToRCH, P. 2015. Graptolites from Rhuddanian-Aeronian boundary interval (Silurian) in the Prague Synform, Czech Republic. Bulletin of Geosciences 90(4), 841-891. DOI 10.3140/bull. geosci. 1568

Štorch, P. \& Kraft, P. 2009. Graptolite assemblages and stratigraphy of the lower Silurian Mrákotín Formation, Hlinsko Zone, NE interior of the Bohemian Massif (Czech Republic). Bulletin of Geosciences 84(1), 51-74. DOI 10.3140/bull.geosci.1077

Štorch, P., Manda, Š., TasÁryová, Z., FrÝda, J., Chadimová, L. \& Melchin, M.J. 2018. A proposed new global stratotype for Aeronian Stage of the Silurian System: Hlásná Třeban̆ section, Czech Republic. Lethaia 51, 357-388. DOI 10.1111/let.12250

Sudbury, M. 1958. Triangulate monograptids from the Monograptus gregarius Zone (Lower Llandovery) of the Rheidol Gorge (northern Cardiganshire). Philosophical Transactions of the Royal Society of London, Series B 241, 485-555. DOI 10.1098/rstb.1958.0011

Sudbury, M. 1959. Monograptus triangulatus. Geological Magazine 96, 171-172. DOI 10.1017/S0016756800060088

Sudbury, M. \& Hutt, J. 2000. Monograptus triangulatus separatus Sudbury, 1958. Atlas of Graptolite Type Specimens, Folio 1.64.

TöRnquist, S.L. 1899. Researches into the Monograptidae of the Scanian Rastrites Beds. Lunds Universitets Arsskrifter 35, $1-25$.

TöRnquist, S.L. 1907. Observations on the genus Rastrites and some allied species of Monograptus. Lunds Universitets Arsskrifter (NS), Afd. 2, 3, 5, 1-22.

Wilkinson, J. 2018. Monograptus triangulatus fimbriatus (Nicholson, 1868). Atlas of Graptolite Type Specimens, Folio 3.32.

Willefert, S. 1963. Les Graptolites du Silurien inferieur du jbel Eguer-Iguiguena (SW d'Ito anticlinorium de KasbaTadla-Azrou, Maroc central). Notes et Mémoires du Service geologique, Rabat 177, 1-70.

ZaLasiewicz, J. 2007. Monograptus triangulatus triangulatus (Harkness, 1851). Atlas of Graptolite Type Specimens, Folio 2.92 .

Zalasiewicz, J.A., Taylor, L., Rushton, W.A., Loydell, D.K., Rickards, R.B. \& Williams, M. 2009. Graptolites in British stratigraphy. Geological Magazine 146, 785-850.

DOI $10.1017 / \mathrm{S} 0016756809990434$ 